\title{
Algal biofuel production for fuels and feed in a 100-ha facility: a comprehensive techno-economic analysis and life cycle assessment
}

Colin M. Beal ${ }^{*}$, Léda N. Gerber ${ }^{2,3}$, Deborah L. Sills ${ }^{4}$, Mark E. Huntley ${ }^{5,6}$, Stephen C. Machesky $^{7}$, Michael J. Walsh ${ }^{8}$, Jefferson W. Tester ${ }^{3,9}$, Ian Archibald ${ }^{10}$, Joe Granados ${ }^{11}$, Charles H. Greene ${ }^{2}$

${ }^{1}$ B\&D Engineering and Consulting LLC, 7419 State Hwy 789, Lander, WY 82520, United States

${ }^{2}$ Cornell University, Department of Earth and Atmospheric Sciences, 4120 Snee Hall, Ithaca, NY 14853, United States

${ }^{3}$ Cornell University, Department of Chemical and Biomolecular Engineering, 120 Olin Hall, Ithaca, NY 14853, United States

4 Bucknell University, Department of Civil and Environmental Engineering, 215 Dana Engineering, Lewisburg, PA 17837, United States

${ }^{5}$ Cornell University, Department of Biological and Environmental Engineering, Riley-Robb, 111 Wing Drive, Ithaca, NY 14853, United States

${ }^{6}$ Duke University, Marine Laboratory, Nicholas School of the Environment, 135 Duke Marine Lab Road, Beaufort, NC 28516, United States

${ }^{7}$ KCPM, Inc. dba Kokua Contracting and Project Management, 77-6441 Kuakini Hwy, KailuaKona, HI 96740, United States

8 Center for Integration of Science and Industry, Bentley University, 110 Jennison Hall, Waltham, MA 02425, United States

${ }^{9}$ Cornell University, Cornell Energy Institute, 2160 Snee Hall, Ithaca, NY 14853, United States

${ }^{10}$ Cinglas Ltd, Chester, United Kingdom

11 Institute for Integrated Renewables, 73-4617 Kaloko Halia Place, Kailua-Kona, HI 96740, United States

* Corresponding author. Tel: +1 540-230-5049, E-mail address: colinmbeal@gmail.com 


\section{ABSTRACT}

This techno-economic analysis/life-cycle assessment is based on actual production by the Cornell Marine Algal Biofuels Consortium with biomass productivity $>23 \mathrm{~g} / \mathrm{m}^{2}-\mathrm{d}$. Ten distinct cases are presented for two locations, Texas and Hawaii, based on a 100-ha production facility with end-to-end processing that yields fungible co-products including biocrude, animal feed, and ethanol. Several processing technologies were evaluated: centrifugation and solvent extraction (POS Biosciences), thermochemical conversion (Valicor), hydrothermal liquefaction (PNNL), catalytic hydrothermal gasification (Genifuel), combined heat and power, wet extraction (OpenAlgae), and fermentation. The facility design was optimized by co-location with waste $\mathrm{CO}_{2}$, a terraced design for gravity flow, using renewable energy, and low cost materials. The case studies are used to determine the impact of design choices on the energy return on investment, minimum fuel and feed sale prices, discounted payback period, as well as water depletion potential, human health, ecosystem quality, non-renewable resources, and climate change environmental indicators. The most promising cases would be economically competitive at market prices around $\$ 2 / \mathrm{L}$ for crude oil, while also providing major environmental benefits and freshwater savings. As global demands for fuels and protein continue rising, these results are important steps towards economical and environmentally sustainable production at an industrial scale.

KEYWORDS: Algae, Biofuel, Animal Feed, Life-cycle Assessment, Techno-economic Analysis 


\section{INTRODUCTION}

Algae are among the most promising feedstock candidates to produce second-generation biofuels that satisfy the national mandate in the Renewable Fuels Standards that was enacted into United States' law in the Energy Independence and Security Act of 2007.[1] Marine algae are especially promising because they do not require arable land or freshwater - thereby avoiding competition with conventional crops for these resources - and they often contain large quantities of oil, protein, carbohydrates, omega-3 fatty acids, and pigments such as astaxanthin. However, the flurry of investment into algal biofuels in the late 2000s in both public and private sectors [24] has not yielded economical large-scale algal biofuel production due to the following barriers: unreliable cultivation methods, large nutrient requirements (for carbon, nitrogen, and phosphorus), low energy return on investment (EROI), high capital costs, and competition from existing commodity products with tight margins (primarily crude oil, soy meal, and corn meal).[5-9]

We address all of these barriers in this study in the following ways: Biomass productivity was measured during extended demonstration-scale experiments with consistently high yields from two selected strains (as described in a companion manuscript [10]). The facility modeled in this study is co-located with a carbon dioxide waste stream and utilizes nutrient recycling in most scenarios. Using gravity-fed volume transfers, airlift pond circulation, naturally settling algal species, and efficient conversion/extraction processes, the EROI values obtained in this model are among the highest ever reported. Low capital costs were targeted by designing large cultivation systems to achieve economies of scale, specifying cost-effective pond liners, using multi-purpose pipelines to reduce pipe costs, and eliminating most pumps. Current market prices were used for valuing the biofuel and animal feed, however, the animal feed was shown to have 
several added benefits over conventional feeds during feed trials with poultry, swine, and fish, such as the high content of protein and omega-3 fatty acids - thereby potentially warranting greater financial value.[11, 12]

Of the many recent techno-economic analyses (TEA) and life-cycle assessments (LCA) describing the production of biofuel from algae, most evaluate a few selected production pathways based on assumed or modeled biomass and lipid yields for a specific geographical location and the TEA/LCA is conducted after the system (theoretical or experimental) has been designed.[4, 6, 13-23] By contrast, in this study, we used actual large-scale production results to evaluate a wide range of processing technology combinations for two geographic locations (Texas and Hawaii) and then employed TEA/LCA as a design tool, using the results of one processing scenario to inform design choices for subsequent iterations. This combination is critical to avoid recommending environmentally friendly designs that are not profitable, and vice versa.

There have been a wide range of functional units used for algal biofuel TEA/LCA studies [14, 24-26] and we chose 1 ha of facility area to enable comparisons with conventional crops and avoid allocation of environmental impacts among co-products.[27] The TEA/LCA analysis yields results for 20 cases in the following metrics: EROI (unitless), minimum feed and fuel sale prices (in $\$ / M T$ and $\$ / L$, respectively), discounted payback period (in years) and the LCA impacts of water depletion potential $\left(\mathrm{m}^{3} /\right.$ ha over a 30 year span), human health, ecosystem quality, non-renewable resources, and climate change (all of which are reported in units of LCA points of environmental damage per hectare). Thus, by combining the large-scale experimental biomass productivity data with novel technology designs and thorough TEA/LCA analysis, this 
study offers a realistic and comprehensive evaluation of the emerging algal biofuels and animal feed industries.

\section{MATERIAL AND METHODS}

\subsection{The Model}

This study evaluates a nominal 100-ha facility model that justifiably expands on the Kona Demonstration Facility (KDF), which is now Cellana LLC - as described by Huntley [10] - and does not exceed reasonable capital finance (on the order of tens-of-millions of dollars). The KDF was used from April 2010 to August 2011 for sustained production in a 0.5-ha hybrid cultivation system of photobioreactors (PBRs) and open ponds that yielded $>23 \mathrm{~g} / \mathrm{m}^{2}-\mathrm{d}$ of biomass productivity.[10] Cultivation of two algal species (a diatom, Staurosira sp., and a chlorophyte, Desmodesmus sp.) is modeled based on actual KDF results and both species are cultivated in seawater. In the model, carbon is obtained from a local waste stream while other nutrients (nitrogen, phosphorus, and silicon, when applicable) are provided from commercial fertilizers. Co-location with a wastewater treatment plant was considered [28, 29], however the nutrient demand for high-rate biomass production exceeds the low nutrient content in most wastewater primary effluents; in our analysis, the cost of pipes and pumping outweighed the nutrient savings. The facility is designed in terraces, enabling low-energy water recycling, and the cultivation system is modeled as a hybrid system of PBRs and ponds.[10] Based on the authors' experience with large-scale algae production in this integrated system, the facility is assumed to operate 347 days per year, which corresponds to a 95\% capacity factor.

Several processing technology configurations were evaluated in this study. The harvesting and dewatering methods considered include 1) natural settling [10] followed by centrifugation [30- 
$32]$ and a ring dryer [33] (yielding 90\% solids), and 2) natural settling and a belt filter press [22, $32,34,35]$ (yielding $20 \%$ solids). The extraction/conversion processes in this study include combinations of hexane extraction [14,36], Valicor's thermochemical conversion technology [37], hydrothermal liquefaction (HTL) [7, 38], OpenAlgae's lipid extraction process [39], ethanol fermentation [40], catalytic hydrothermal gasification (CHG) [38], and combined heat and power (CHP) [40]. The output products include biocrude, protein-rich and omega-3-fattyacid rich animal feed, and ethanol. Livestock feed and aquafeed trials were conducted in parallel $[11,12]$ and demonstrate the ability to use algae as protein-rich animal feed and justify the coproduct value assigned to the residual biomass after biocrude separation.

\section{$\underline{2.2 \text { Facility Design }}$}

The cultivation process is described by Huntley et al. [10] and the modeled facility (Appendix A of the supplemental information (SI)) in this study contains 480 PBR's with $50 \mathrm{~m}^{3}$ of culture volume each, 16 1-day ponds, and 64 2-day ponds, both of which contain 1,500 $\mathrm{m}^{3}$ of growth volume per pond. The total facility culture volume is $114,000 \mathrm{~m}^{3}$. Each PBR has $250 \mathrm{~m}^{2}$ of lit area and each pond has $10,000 \mathrm{~m}^{2}(1 \mathrm{ha})$ of lit area, yielding a total lit growth area for the facility of 92 ha. As shown in Appendix A of the SI, the 111 ha facility is a rectangular land plot with 11 terraces built into a natural $1 \%$ slope that enable gravity-fed volume transfers. Contrary to previous land assessments [41], this design is suitable for natural grades steeper than $1 \%$; steeper slopes require more site preparation, but allow faster volume transfers and/or smaller pipe sizes. The upper terrace contains a parking lot, office and lab facilities, a seawater reservoir, nutrient stock tanks, and PBRs. New seawater is acquired from an offshore water intake located $5 \mathrm{~km}$ from the Texas site and a saline aquifer well (17 m depth) in the Hawaii location. Each of the main terraces contains one 1-day pond and four 2-day ponds on either side of the access road. 
Each day, $50 \%$ of all PBRs are harvested and combined to inoculate the 1-day ponds. The 1-day ponds are drained entirely each day and used to inoculate the 2-day ponds, half of which are harvested daily. As described in Appendix B of the SI, the daily volume transfers are initiated by harvesting the lowest main terrace - the algal sludge is sent to downstream processing and the supernatant is discharged. Once the lowest ponds are emptied, the second-lowest terrace is harvested - the algal sludge is sent to downstream processing and the supernatant is sent to the lowest terrace for reuse. This process is repeated as the harvesting process moves uphill. New seawater is supplied from the reservoir as needed. All cases require roughly $27,000 \mathrm{~m}^{3}$ of new seawater each day, which represents roughly $75 \%$ daily seawater recycling. Salinity increases as the seawater is reused (due to evaporation at $2.8 \%$ per day [42]) and the discharged seawater from the lowest terrace contains $39 \mathrm{~g}$ of salt/L, which is non-inhibitory for algal growth (authors' experience with these species).

\subsection{Case Descriptions}

Ten distinct cases were constructed and evaluated in two geographical locations, yielding a total of twenty case studies. The ten cases are summarized in Table 1, illustrated in Figure 1, and Appendix C of the SI contains a description of the detailed operations for each process. There are two company-specific processes included in this study: 1) the Valicor thermochemical conversion process that converts wet biomass into biocrude, a carbohydrate-rich aqueous phase, and dry residual biomass [37], and 2) the OpenAlgae extraction process that utilizes a semipermeable membrane to recover lipids from an algal slurry [29, 39]. The biomass productivity and composition for both species is based directly on experimental measurements from largescale cultivation as described by Huntley et al.[10] The remainder of the data is modeled. Some processes were used during large scale production or experimentally tested for proof of principle, 
but lack published experimental data: natural settling, centrifugation, ring drying, POS hexane extraction, and the Valicor thermochemical conversion process. Although these processes were used, experimental data for all energy and mass throughputs were not directly measured for the processing of Stuarosira and Desmodesmus from Cellana. Instead, these processes are modeled based on information from the companies that provided the equipment or conducted the processing. Processes that were not tested during this project, and therefore rely on literature data for modeling, include: belt filter press, HTL, OpenAlgae's extraction method, fermentation, CHG, and CHP. Generally speaking, Case 1 is based on experimental procedures employed during this project, Cases 2-8 are base cases representing the current state of technologies, and Cases 9 and 10 are target cases with optimistic parameters.

Case 1 includes conditions and processes that were experimentally validated during low-nitrogen production of Staurosira sp. at the KDF, although some of the processes are known to be inefficient (e.g., paddlewheel circulation, centrifugation, and ring drying). Cases 2 and 3, which are identical in design except for the nitrogen fertilizer dose, model more efficient methods for cultivation and processing (i.e., airlift pond circulation, filter press dewatering, and Valicor's thermochemical conversion process) for low-nitrogen and high-nitrogen Staurosira sp. production scenarios, respectively. Case 4 is identical to Case 3 except that Desmodesmus $\mathrm{sp}$. is grown, thereby eliminating the need for silicate. Desmodesmus sp. is modeled in all subsequent cases (Cases 5-10). In Cases 2-4, the carbohydrate-rich aqueous phase produced from Valicor's thermochemical conversion process is gasified via $\mathrm{CHG}$ and the resulting biogas is used for CHP with the produced heat and electricity being used onsite. Case 5 is identical to Case 4 except that the aqueous phase is fermented to produce ethanol rather than used for CHG/CHP. Case 6 is identical to Case 4 except that electricity is provided from wind power $(\$ 0.07 / \mathrm{kWh}$ in Texas and 
Hawaii $[43,44]$ with significant LCA impact reductions) rather than grid electricity in those locations $(\$ 0.06 / \mathrm{kWh}$ in Texas and $\$ 0.31 / \mathrm{kWh}$ in Hawaii [45]).

Cases 7 and 8 replace the Valicor conversion process with HTL [38] and the OpenAlgae wet extraction process [29, 39], respectively. Cases 9 and 10, which can be considered target cases, also use the HTL and OpenAlgae conversion processes, respectively, and assume low-cost pond liners, utilize wind power, and reduce pond circulation duty cycles.

The geographic locations impact the results in three ways: 1) the energy and cost of acquiring new seawater varies for Texas (an offshore intake with $5 \mathrm{~km}$ of pipeline) and Hawaii (a saline aquifer); 2) where location-specific costs are not known, geographic cost modifiers are used to scale the associated operating, capital, or labor cost in relation to the average cost in the United States for Texas (0.88) and Hawaii (1.37) [46]; and 3) when available, data from the ecoinvent(C) version 3 LCA database were selected for the respective locations (e.g., emissions from the Texas electricity grid versus those in Hawaii) [47].

The system boundary for this analysis extends to the "facility gate," with some combination of biocrude, animal feed, and/or ethanol co-products exiting the facility in each case. For this assessment, it is assumed that the product yields from different technologies (e.g., biocrude produced by hexane extraction, Valicor, HTL, and OpenAlgae are equivalent and the animal feed co-product is also equivalent among cases). However, composition differences might exist between these products in practice, thereby requiring different upgrading methods, and determining proper upgrading methods remains as future work. 






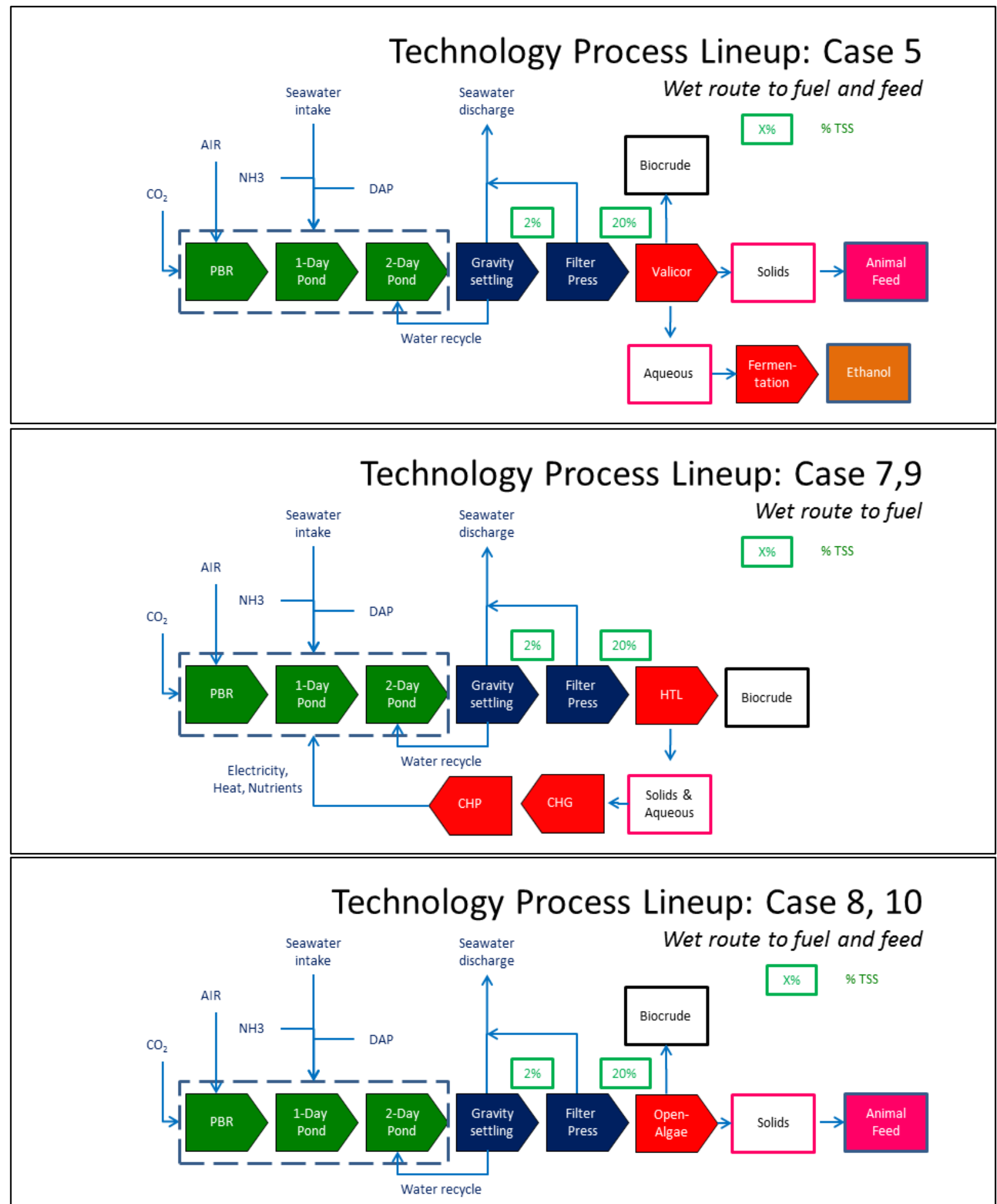

Figure 1. Process flow diagrams for all cases. Several cases share identical processing pathways: Cases 2, 3, 4, and 6 are based on the Valicor process; Cases 7 and 9 are based on HTL; and Cases 8 and 10 are based on the OpenAlgae process. All cases are described in Table 1 and Table $\mathrm{C}-1$ of Appendix $\mathrm{C}$ in the SI. 
Table 1. The 10 cases include two algal species and various growth and processing configurations. All 10 are evaluated in Texas and Hawaii. In all cases, carbon is provided from an industrial point-source as a $94 \%$ pure $\mathrm{CO}_{2}$ waste stream located $15 \mathrm{~km}$ from the facility. The nutrients in Case 1 are sodium nitrate and sodium phosphate (the same as those used at KDF), while the nutrients for Cases 2-10 are ammonia and diammonium phosphate (DAP). Productivity (in $\mathrm{g} / \mathrm{m}^{2}-\mathrm{d}$ ) is normalized to the total facility area. Confer Table C-1 in Appendix C of the SI for more details.

\begin{tabular}{|c|c|}
\hline Case Number & Key Features \\
\hline Case 1 (Demonstration) & $\begin{array}{l}\text { Low-N, Staurosira sp., paddle-wheel pond circulation } 24 \mathrm{hrs} / \mathrm{d} \text {, hypalon pond liner }\left(\$ 30 / \mathrm{m}^{2}\right), 19 \mathrm{~g} \mathrm{DW} / \mathrm{m}^{2}-\mathrm{d}, 0.246 \\
\mathrm{~g} \text { AFDW/L at harvest, } 31 \% \text { lipid,18 MT biomass/day, natural settling + centrifuge + ring dryer, hexane extraction }\end{array}$ \\
\hline Case 2 (Low-N) & $\begin{array}{l}\text { Low-N, Staurosira sp., airlift pond circulation } 16 \mathrm{hrs} / \mathrm{d} \text {, RPP pond liner }\left(\$ 13 / \mathrm{m}^{2}\right), 19 \mathrm{~g} \mathrm{DW} / \mathrm{m}^{2}-\mathrm{d}, 0.246 \mathrm{~g} \text { AFDW/L } \\
\text { at harvest, } 31 \% \text { lipid, } 18 \mathrm{MT} \text { biomass } / \text { day, natural settling + filter press, Valicor extraction with CHG/CHP }\end{array}$ \\
\hline Case 3 (High-N) & $\begin{array}{l}\text { High-N, Staurosira sp., airlift pond circulation } 16 \mathrm{hrs} / \mathrm{d} \text {, RPP pond liner }\left(\$ 13 / \mathrm{m}^{2}\right), 33 \mathrm{~g} \mathrm{DW} / \mathrm{m}^{2}-\mathrm{d}, 0.424 \mathrm{~g} \text { AFDW/L } \\
\text { at harvest, } 36 \% \text { lipid, } 30 \mathrm{MT} \text { biomass/day, natural settling + filter press, Valicor extraction with CHG/CHP }\end{array}$ \\
\hline Case 4 (High-N Green) & $\begin{array}{l}\text { High-N, Desmodesmus sp., airlift pond circulation } 16 \mathrm{hrs} / \mathrm{d} \text {, RPP pond liner }\left(\$ 13 / \mathrm{m}^{2}\right), 23 \mathrm{~g} \mathrm{DW} / \mathrm{m}^{2}-\mathrm{d}, 0.433 \mathrm{~g} \\
\text { AFDW/L at harvest, } 38 \% \text { lipid, } 22 \mathrm{MT} \text { biomass/day, natural settling }+ \text { filter press, Valicor extraction with } \\
\text { CHG/CHP }\end{array}$ \\
\hline Case 5 (Fermentation) & Same as Case 4 except fermentation of aqueous phase rather than $\mathrm{CHG} / \mathrm{CHP}$ \\
\hline Case 6 (Wind) & Same as Case 4 except wind power is used \\
\hline Case 7 (HTL) & Same as Case 4 except HTL used for extraction/conversion \\
\hline Case 8 (OpenAlgae) & Same as Case 4 except OpenAlgae process is used for extraction/conversion \\
\hline Case 9 (Target HTL) & $\begin{array}{l}\text { High-N, Desmodesmus } s p . \text {, airlift pond circulation } 12 \mathrm{hrs} / \mathrm{d} \text {, low cost ponds }\left(\$ 3 / \mathrm{m}^{2}\right), 23 \mathrm{~g} \mathrm{DW} / \mathrm{m}^{2}-\mathrm{d}, 0.433 \mathrm{~g} \\
\text { AFDW/L at harvest, } 38 \% \text { lipid, } 22 \mathrm{MT} \text { biomass/day, natural settling + filter press, HTL, wind power }\end{array}$ \\
\hline Case 10 (Target OpenAlgae) & $\begin{array}{l}\text { High-N, Desmodesmus sp., airlift pond circulation } 12 \mathrm{hrs} / \mathrm{d} \text {, low cost ponds }\left(\$ 3 / \mathrm{m}^{2}\right), 23 \mathrm{~g} \mathrm{DW} / \mathrm{m}^{2}-\mathrm{d}, 0.433 \mathrm{~g} \\
\text { AFDW/L at harvest, 38\% lipid, } 22 \mathrm{MT} \text { biomass/day, natural settling + filter press, OpenAlgae, wind power }\end{array}$ \\
\hline
\end{tabular}




\section{$\underline{2.4 \text { Assessment Methods }}$}

\subsubsection{Energetic Methods}

The EROI provides a direct comparison not only between the energy inputs and outputs of each case, but also among other energy production technologies. We calculate the EROI as the ratio of (total) energy outputs $\left(E_{\text {out }}\right)$ to (total) energy inputs $\left(E_{\text {in }}\right)$,

1

$$
E R O I=\frac{E_{\text {out }}}{E_{\text {in }}}=\frac{E_{B C}+E_{E t O H}+E_{A F}}{E_{E}+E_{H}+\sum E_{M A T L}} \quad\left[\frac{M J / d}{M J / d}\right]
$$

where $E_{B C}$ is the energy output from biocrude $(53.0 \mathrm{MJ} / \mathrm{kg}), E_{E t O H}$ is the energy output from ethanol $(41.9 \mathrm{MJ} / \mathrm{kg}), E_{A F}$ is the energy credit from animal feed $(25.1 \mathrm{MJ} / \mathrm{kg}), E_{E}$ is the energy input from electricity (3.8 MJ/MJ for the Texas grid, 3.9 MJ/MJ for the Hawaii grid, and 1.13 $\mathrm{MJ} / \mathrm{MJ}$ for wind power), $E_{H}$ is the energy input from heat (1.2 MJ/MJ), and $\sum E_{M A T L}$ is the sum of all embedded energy inputs from operating materials (confer Appendix D in the SI).[47] When on-site heat or electricity (produced from $\mathrm{CHG}+\mathrm{CHP}$ ) is used the associated amount is subtracted from the inputs in the denominator. If the non-renewable energy impacts are used rather than the total energy impacts, the EROI results change significantly, especially for the cases with wind power and large oil yields (confer section 3.2 Sensitivity Analysis).

\subsubsection{Economic Methods}

Two economic evaluations were conducted: 1) a discounted cash flow analysis assuming current market prices for all output products and assuming a 30-year facility lifetime, and 2) the minimum biocrude sale price and the minimum animal feed sale price were determined for a 30year payback period and the current market price for either the animal feed (when determining the minimum biocrude sale price) or the biocrude (when determining the minimum animal feed 
price). For Case 5, which includes ethanol as a co-product, the minimum animal feed and biocrude price calculations also assume the current market price for ethanol. A 30-year facility lifetime was selected because the pond liners are guaranteed for 20 years and the HDPE pipes have >30 year lifespans (the two greatest contributors to capital cost), and there is a large maintenance budget.

\subsubsection{Capital Costs}

Capital costs were estimated using a methodology and data from RS Means with an estimated 20\% uncertainty.[46] The costs are detailed in Appendix F of the SI and include the following categories: general requirements, site work (including cut-and-fill terracing), concrete, masonry, metals, wood and plastic, thermal and moisture protection, doors and windows, finishes, specialties, equipment, furnishings, special construction, conveying systems, mechanical systems, and electrical systems. The depreciable capital cost omits general requirements and site work and is roughly $90 \%$ of the total capital cost for all cases.

\subsubsection{Operating Costs}

Operating costs include the following contributions: energy, materials, land, maintenance, insurance, loan payments, taxes, and labor. The amounts of each energy and material input were determined from the integrated model of each case (including energy, mass, volume, and nutrient balances), as detailed in Appendix $\mathrm{C}$ of the SI. The operating energy and material costs $\left(C_{E \& M}\right)$ determined for each case are listed in Appendix D of the SI along with their assumed market prices for Texas and Hawaii.

The annual land lease $\left(C_{\text {land }}\right)$ is $\$ 6.50 / \mathrm{ac}-\mathrm{yr}$ in Texas and $\$ 15 / \mathrm{ac}-\mathrm{yr}$ in Hawaii.[48] The annual maintenance cost $\left(C_{m t n}\right)$ and the annual insurance costs $\left(C_{i n s}\right)$ are both set equal to $1 \%$ of the 
facility depreciable capital cost. The model assumes that capital costs are split between equity $(40 \%)$ and a 10 -year project financing loan $(60 \%)$ with an annual loan payment $\left(C_{\text {loan }}\right)$ determined by an $8 \%$ interest rate. The annual tax payment $\left(C_{\text {tax }}\right)$ applies depreciation of assets using a 7-year Modified Accelerated Cost Recovery System (MACRS) schedule [49] and losses were continuously carried forward. Tax liability on net income was calculated using a $20 \%$ rate.

Labor costs $\left(C_{\text {labor }}\right)$, detailed in Appendix E of the SI, were taken from Huntley [10] (specified for the same facility as modeled in this study) and determined by estimating the number of laborers, scientists, engineers, contractors, maintenance workers, and administrators needed to operate the production facility. There are 41 full-time equivalent employees and salaries include $30 \%$ fringe benefits.

Therefore, the annual operating cost $\left(C_{a o p}\right)$ is expressed as

2

$$
C_{\text {aop }}=C_{E \& M}+C_{\text {land }}+C_{m t n}+C_{\text {ins }}+C_{\text {loan }}+C_{\text {tax }}+C_{\text {labor }}
$$

\subsubsection{Discounted Payback Period}

A discounted cash flow model using an internal rate of return (i.e., discount rate) of 10\% was used to assess financial feasibility. The discounted payback period represents the length of time it takes for the facility to achieve a financial break-even point (i.e., a net present value (NPV) equal to zero), assuming that the fuel and feed are sold at certain market prices. The discounted payback period $(D P B)$ is calculated by solving

$$
\sum_{k=0}^{D P B} D C F_{k}=0[\mathrm{yr}]
$$


where $D C F_{k}$ is the discounted cash flow associated with the facility for year $k$. Facility construction occurs during year 0 and full operation begins in year 1 . Therefore $D C F_{k}$ is calculated by:

4

$$
\text { for } k=0 \quad D C F_{0}=C_{e q} \quad[\$ / \mathrm{yr}]
$$

where $C_{e q}$ is the equity portion of the total capital cost (40\%) and

5

$$
\text { for } k \geq 1 \quad D C F_{k}=\frac{R_{t o t}-C_{a o p}}{(1+i)^{k}}
$$

where $R_{\text {tot }}$ is the annual revenue from product sales, $C_{\text {aop }}$ is the annual operating expense of the facility, and $i$ is the discount rate $(i=10 \%)$.

\subsubsection{Minimum selling price of fuel or feed}

The minimum selling price of biocrude $\left(P_{\min , B C}\right)$ or feed $\left(P_{\min , f e e d}\right)$ represents the price at which one product has to be sold for the facility to break-even after a certain period, assuming the other products are sold at certain prices. Excel Solver was used to nonlinearly optimize $P_{\min }$ for biocrude or animal feed with the price of the other co-products being fixed, assuming a 30-year facility life. To determine $P_{\min , B C}$, the price of feed was fixed at $\$ 600 / \mathrm{MT}$ in Texas and $\$ 930$ Hawaii.[50] Conversely, to determine $P_{\min , f e e d}$ the price of biocrude was set to $\$ 0.58 / \mathrm{L}$ in Texas and $\$ 0.91 / \mathrm{L}$ in Hawaii.[51] For Case 5, ethanol was fixed at $\$ 0.59 / \mathrm{L}$ in Texas and $\$ 0.93 / \mathrm{L}$ of ethanol in Hawaii.[52]

\subsubsection{Environmental Impact Metrics}

The LCA was conducted according to ISO standards $[53,54]$ with the objective of assessing environmental impacts associated with the ten cases studies defined in Table 1 for Texas and 
Hawaii. The functional unit is 1 ha of facility area, including cultivation, processing, and general facilities. The LCA was conducted by implementing the integrated case models and their corresponding life cycle inventories in the OSMOSE software system [55], which interfaces directly with the ecoinvent $(\mathrm{C}$ version 3 database [47]. Details of the life cycle inventories can be found in Appendix G of the SI. The Impact2002+ impact assessment method [56] was applied to yield four endpoint categories: human health, ecosystem quality, non-renewable resources, and climate change (all of which are described in Appendix G of the SI [57]). The weighting factors for the final results are specific to the USA, using the results from Lautier et al.[57] All categories are reported in units of LCA points per hectare, which enables results from across the four categories to be compared for relative impact. One point corresponds to the yearly impacts generated per capita in the USA in each endpoint category. Water depletion potential, not available with Impact2002+, was included as a fifth indicator of environmental performance, using the Recipe impact assessment method [58], and is expressed in $\mathrm{m}^{3}$ of depleted water over a 30 year period. Details of the LCA method can be found in Appendix G of the SI.

\section{RESULTS AND DISCUSSION}

\section{$\underline{3.1 \text { Results }}$}

\subsubsection{Energy}

The energy inputs and outputs for all 20 cases are shown in Figure 2. The energy impacts assigned to each contribution are listed in Table D-3 of the SI. Case 1 incorporates inefficient methods that yield high energy requirements and a low-nitrogen growth setting with lower productivity than the high-nitrogen cases. Case 2 improves upon Case 1 by using more efficient technologies and Case 3 applies a high-nitrogen growth setting with higher yields, further improving the EROI with respect to Case 1. Case 4 (Desmodesmus sp.) has a greater oil content 
than Case 3 (Staurosira sp.) and no silicon requirement, but the EROI is less than Case 3 because there is less animal feed produced, which receives large displacement credit. Fermentation of the aqueous phase produced during the Valicor process (Case 5) results in a slight reduction in the EROI as compared to Case 4 due to energy required to distill the ethanol produced by fermentation. Implementing wind power (Cases 6,9, and 10) provides major energy savings, reducing the energy impact for electricity from roughly 3.85 to $1.13 \mathrm{MJ} / \mathrm{MJ}$. HTL provides the most energetically advantageous separations/conversion method (Cases 7 and 9), yielding an EROI above 8 in Case 9H, which is among the highest EROI reported to-date for an end-to-end algae fuel scenario. The benefits of HTL include large biocrude yields, on-site electricity and heat production, and low embedded energy inputs due to high levels of nutrient recycling. The OpenAlgae process (Cases 8 and 10) is quite similar energetically to the Valicor process, but provides slight improvements in this assessment by reducing the heat required for extraction. All of the Hawaii cases result in greater EROI values than their Texas counterparts because the water supply energy is significantly less for drilled wells in Hawaii versus a $5 \mathrm{~km}$ pipeline in Texas. For Cases 2-10 in Texas, the water supply energy accounts for over $25 \%$ of the total energy input, whereas all of the cases in Hawaii require less than $25 \%$ of the total energy input for water supply. 


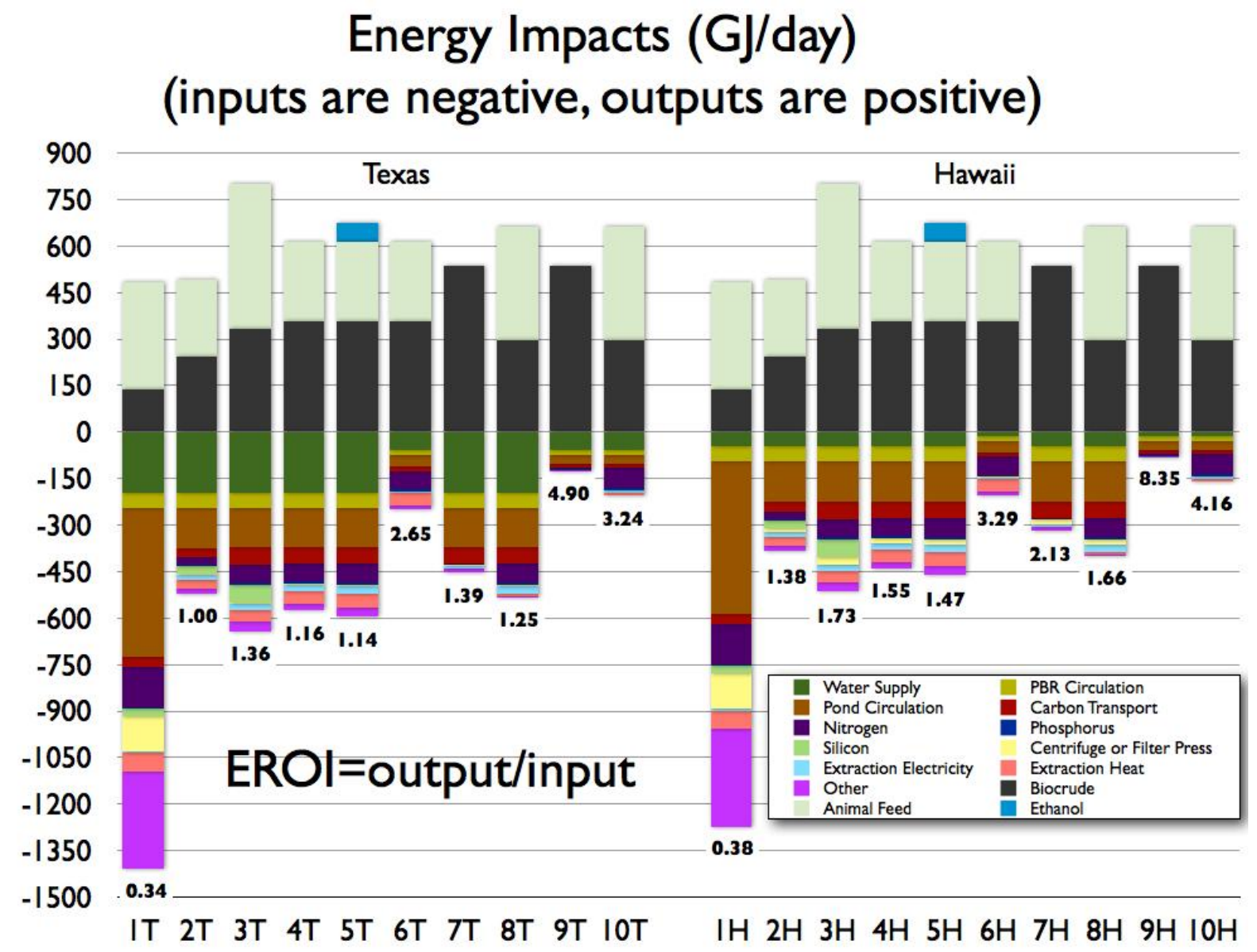

Figure 2. Energy impacts for the ten cases in Texas (T) and Hawaii (H). All inputs (e.g., electricity, measured in MJ/day, and nitrogen fertilizer, measured in kg/day) are shown in Tables D-1 and D-2 and they are scaled by their associated energy impact factor (e.g., $\mathrm{MJ} / \mathrm{MJ}$ or $\mathrm{MJ} / \mathrm{kg}$ ), which are listed in Table D-3 such that all inputs and outputs are reported in MJ/day and include upstream life-cycle impacts. The EROI for each case is shown in bold below the corresponding bar. On-site electricity and heat generation are not shown. For areal energy value calculations, the total facility is 111 ha, the cultivation area (including berms and space between PBRs) is 103 ha, and the sunlit growth area is 92 ha.

\subsubsection{Economics}

The capital costs for all 20 cases are shown in Figure 3 with corresponding data listed in

Appendix F of the SI. The largest contributions to the capital costs are the pond construction

(specifically the Hypalon liner $\left(\$ 30 / \mathrm{m}^{2}\right)$ in Case 1 , RPP liner $\left(\$ 13 / \mathrm{m}^{2}\right)$ in Cases $2-8$, and an

unspecified advanced material $\left(\$ 3 / \mathrm{m}^{2}\right.$, equivalent to clay ponds in [28]) in target Cases 9 and 10 , pipes (included in the Mechanical category), and processing equipment. Pipe costs are greater in Texas due to the water supply pipeline. By contrast, all other capital costs are greater in Hawaii 
than Texas after scaling by the geographic cost modifier in Texas (0.88) and Hawaii (1.37) [46].

The total capital costs in Texas range from $\$ 70 \mathrm{M}$ (Case 1) to $\$ 46 \mathrm{M}$ (Case 10), while those in

Hawaii range from $\$ 95 \mathrm{M}$ (Case 1) to $\$ 46 \mathrm{M}$ (Case 10). The initial debt is $60 \%$ of the total capital cost.

\section{Capital Costs (\$M)}

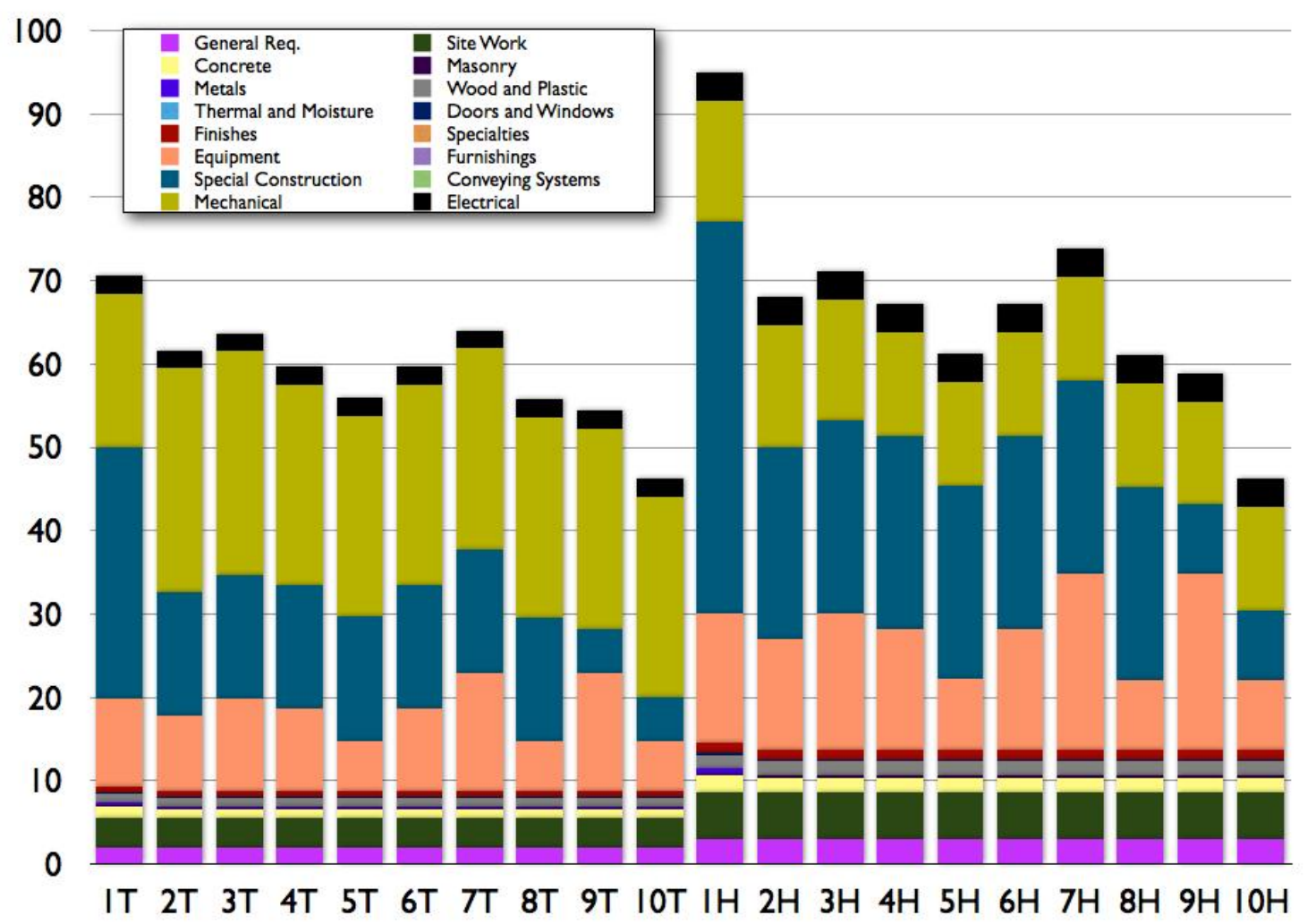

Figure 3. Capital costs for all ten cases in Texas $(\mathrm{T})$ and Hawaii $(\mathrm{H})$ shown in millions of dollars and grouped into the 16 RS Means categories. Capital costs for individual components (e.g., pond liner, water supply pump, HTL equipment, etc.) are listed in Table F-3. In general, pond construction (Special Construction), piping (Mechanical), and processing equipment (Equipment) are the three greatest contributors. For areal cost value calculations, the total facility is 111 ha, the cultivation area (including berms and space between PBRs) is 103 ha, and the sunlit growth area is 92 ha. 
The operating costs and revenues for the entire facility are shown in Figure 4 along with the minimum selling price of animal feed (above each bar) and biocrude (below each bar). The minimum animal feed selling price ranges from $\$ 1,384 / \mathrm{MT}$ to $\$ 5,066 / \mathrm{MT}$, while the minimum biocrude sale prices range from $\$ 1.93 / \mathrm{L}$ to $\$ 20.39 / \mathrm{L}$. Although the product quality from different methods are considered equivalent (e.g., biocrude from hexane extraction, HTL, Valicor, and OpenAlgae), the products might have different compositions that would require different upgrading methods to convert the residual biomass and biocrude to refined products (e.g., diesel fuel, salmon feed, poultry feed, etc.); upgrading was not considered in this study.

Generally speaking, during the loan term (10 years) for most cases, the greatest contributors to the operating cost are the loan payments ( $\sim 50-60 \%)$, energy and materials $(\sim 15-20 \%)$, and labor costs $(\sim 15-20 \%)$ (confer Appendix F of the SI). Maintenance and insurance combine for roughly $10 \%$ of the operating cost during the loan term, while land cost and taxes are negligible. Electricity contributes over $50 \%$ of the energy and materials cost for all cases in Hawaii without wind power, and due to the difference in electricity price in Texas $(\$ 0.06 / \mathrm{kWh}[45])$ and Hawaii $(\$ 0.31 / \mathrm{kWh}[45])$, the total electricity cost in Texas is roughly one-third of that in Hawaii for the corresponding cases. As a result, the total energy and materials cost in Texas is only $37 \%$ to $46 \%$ of that in Hawaii for cases without wind power. At current market sale prices, the only case that generates net annual revenue within the 30 -year facility lifespan is Case $10 \mathrm{H}$, and thus it is the only case that incurs income tax. 


\section{Operating Costs and Revenues $(\$ /$ day) (costs are negative, revenues are positive)}

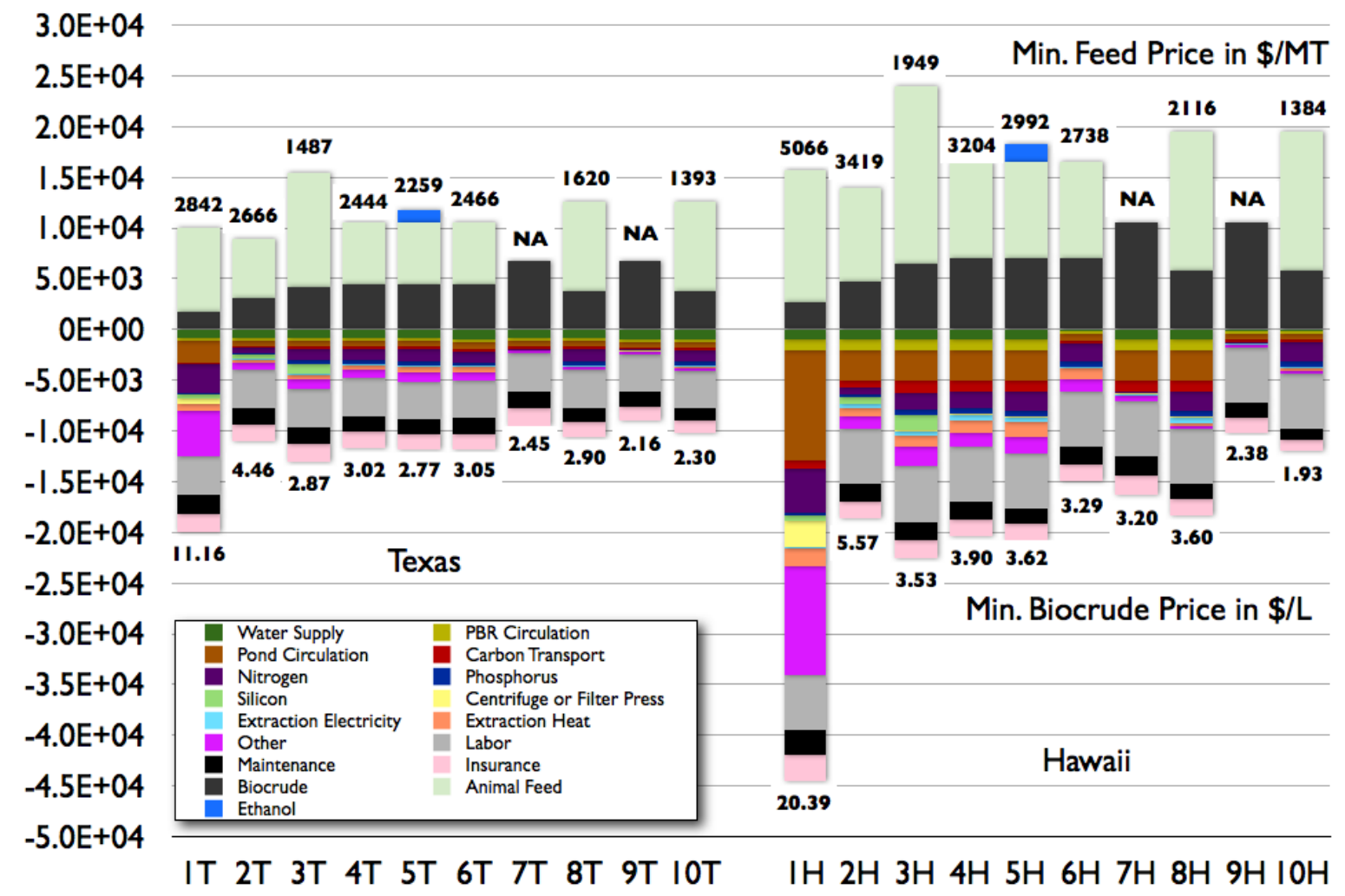

Figure 4. Operating costs and revenues for all ten cases in Texas $(\mathrm{T})$ and Hawaii $(\mathrm{H})$. All inputs (e.g., electricity, measured in MJ/day, and nitrogen fertilizer, measured in kg/day) are shown in Tables D-1 and D-2 and they are scaled by their associated cost/price (e.g., $\$ / \mathrm{MJ}$ or $\$ / \mathrm{kg}$ ), which are listed in Table D-3 such that all inputs and outputs are reported in $\$ /$ day. The minimum sale price for biocrude is shown under each bar in $\$ / \mathrm{L}$ and the minimum sale price for animal feed is shown above each bar in $\$ / \mathrm{MT}$. Onsite electricity and heat generation are not shown. Annual loan payments and taxes vary from year-toyear and are not shown. For areal cost value calculations, the total facility is 111 ha, the cultivation area (including berms and space between PBRs) is 103 ha, and the sunlit growth area is 92 ha.

The cumulative discounted cash flow, which is calculated assuming current market prices for feed and fuel, is presented in Appendix F of the SI. Due to the high capital costs and low revenues associated with current feed and fuel market prices, none of the cases achieve a positive net-present-value within the assumed 30-year lifetime. In fact, none of the cases yield a breakeven scenario within 40 years. This result indicates that at current market prices, none of the scenarios would be profitable, thereby preventing actual investment. Thus, in the absence of 
drastic cost reductions, increased sale prices (such as the minimum biocrude and animal feed prices identified in Figure 4) are needed to generate sufficient revenue to justify investment.

\subsubsection{Life-cycle Assessment}

Life-cycle environmental impacts for five indicators - human health, ecosystem quality, climate change, non-renewable resources, and water depletion - are displayed in Figure 5 for Cases 2 through 10 (impacts for Case 1 are not shown because they are an order of magnitude larger (worse) than the other cases). The impact categories (except water depletion) are normalized to common units of pts/ha $[56,57]$ and this study shows that co-production of biocrude and animal feed has the most significant effects on non-renewable resources, followed by climate change and ecosystem quality (which are similar in magnitude), and finally, the least effect on human health. Generally speaking, almost all of the cases demonstrate neutral or beneficial ecosystem quality, climate change, and water depletion impacts, while some cases are harmful for human health and non-renewable resources are harmful and others are beneficial for these categories. The harmful impacts on human health are caused by the electricity consumption from the grid, which has a high share in fossil resources such as coal, natural gas (Texas case) or oil (Hawaii case). Their combustion is responsible for significant emissions of PAH (poly-aromatic hydrocarbons), $\mathrm{SO}_{\mathrm{x}}$ and $\mathrm{NO}_{\mathrm{x}}$ (sulfur and nitrogen oxides), causing carcinogenic and respiratory effects. Cases 6, 9, and 10 (the three cases with wind-powered electricity) result in beneficial life cycle impacts for all five environmental categories, demonstrating that replacing grid electricity with non-fossil electricity is critical for environmental sustainability.

There are also general differences associated with the processing technologies. The scenarios producing only fuel via HTL (Cases 7 and 9) are most favorable for climate change and resource impacts, whereas the combined fuel-and-feed scenarios (using the Valicor or OpenAlgae process 
- i.e., Cases 2, 3, 4, 5, 6, 8, and 10) are more favorable for ecosystem quality and water depletion potential due to the animal feed substitution. Direct comparisons between the fuel-only route and the fuel-and-feed route can be made by comparing Case 7 (HTL) with Case 8 (OpenAlgae) and by comparing Case 9 (HTL, target case) with Case 10 (OpenAlgae, target case). The tradeoffs among environmental impacts emphasize the importance of considering multiple LCA indicators, and not just one type of impact, such as climate change.

\section{Life Cycle Environmental Impacts (positive is for an overall harmful balance, negative for a beneficial one)}

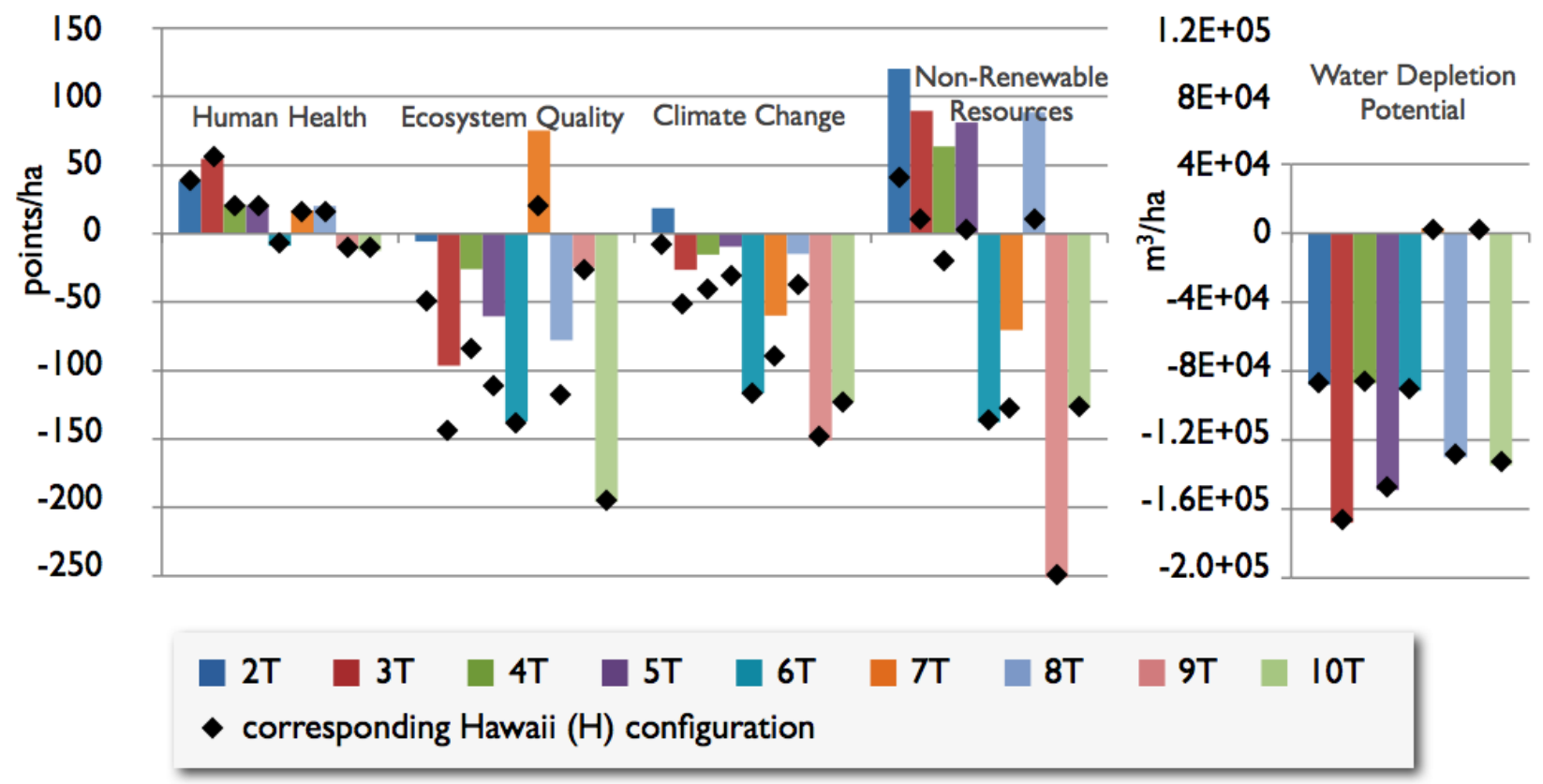

Figure 5. Life Cycle Environmental Impacts calculated with Impact2002+ (categories of Human Health, Ecosystem Quality, Climate Change and Non-Renewable Resources, reported in points/ha) and Recipe (category of water depletion potential, reported in $\mathrm{m}^{3} / \mathrm{ha}$ ). Only cases 2 to 10 for are presented because Case 1 yields environmental impacts well above the other cases. Data for all cases are included in Appendix H of the SI. 
To illustrate the relative impact of individual model components (e.g., electricity, nitrogen fertilizer, animal feed substitution, etc.) on the overall LCA impacts, Figure 6 shows the LCA results for four base case scenarios (Cases 4T, 6T, 7T, and 8T) with discretized impact contributions - thereby illustrating the most harmful impacts and beneficial product substitutions in the model. These four cases were selected as a subset to simplify presentation and because they encompass most of the processing pathways evaluated in this study. Detailed LCA contributions for all cases are presented in Appendix H in the SI.

\section{Details of LCA impact contributions for Cases 4T, 6T, 7T and 8T (positive is for harmful impacts, negative for beneficial substitutions of products)}



Figure 6: Details of contributions to environmental impacts calculated with Impact2002+ (categories of Human Health, Ecosystem Quality, Climate Change and Non-Renewable Resources, reported in points/ha) and Recipe (category of water depletion potential, reported in m3/ha over a 30-year period). Only cases 4, 6, 7 and 8 for Texas are represented here. Results for all cases are included in Appendix $\mathrm{H}$ of the SI. 
As shown in Figure 6, fossil-derived electricity consumption, the animal feed substitution, and the biocrude substitution are the most impactful parameters to the LCA. Favorable ecosystem quality and water depletion impacts for the combined fuel-and-feed scenarios result from the beneficial substitution of algae meal for conventional animal feed (it is assumed that $75 \%$ of the algae meal replaces soybean meal and $25 \%$ of the algae meal replaces corn feed). Meanwhile, the biocrude substitution has favorable impacts for the climate change and resource categories by reducing petroleum consumption and the associated emissions. Grid electricity consumption (mostly associated with cultivation), which is primarily produced from fossil fuel resources in Texas and Hawaii, contributes the vast majority of the negative effects for all five impact categories. Using renewable electricity sources, as in Cases 6, 9 and 10 that use wind power, results in configurations that are beneficial for all impact categories because wind power incurs negligible impacts (see Figure 5).

Because electricity generation is the main contributor to all negative LCA impacts (see Figure 6), the increased electricity demand for water supply in Texas results in more harmful environmental impacts in Texas than in Hawaii for ecosystem quality, climate change, and nonrenewable resources for cases with grid electricity (see Figure 5). However, the human health and water depletion impacts are relatively insensitive to the electricity demand and as a result, the water depletion potential is very similar in both locations because this indicator is dominated by the water-intensive animal feed credit (Figure 6).

\subsubsection{Combined Results}

Figure 7 presents the combined results from the TEA/LCA analysis by plotting the EROI, minimum biocrude sale price, and illustrating the aggregate LCA impact magnitudes (the sum of human health, ecosystem quality, climate change, and resource depletion impacts). As expected, 
the target cases $(9 \mathrm{H}, 10 \mathrm{H}, 9 \mathrm{~T}$, and $10 \mathrm{~T})$ yield the most favorable results in all three metrics, with EROI values between 3.24 and 8.35, minimum biocrude prices between $\$ 1.93$ and $\$ 2.39 / \mathrm{L}$, and aggregate LCA impacts as low as $-500 \mathrm{pts} / \mathrm{ha}$. The Hawaii cases without wind power are roughly $\$ 0.75 / \mathrm{L}$ more expensive than their Texas counterparts, however the EROI in Texas is slightly lower than that in Hawaii. The environmental benefits of the cases with wind power (Cases 6, 9, and 10) are significantly greater than the other cases.

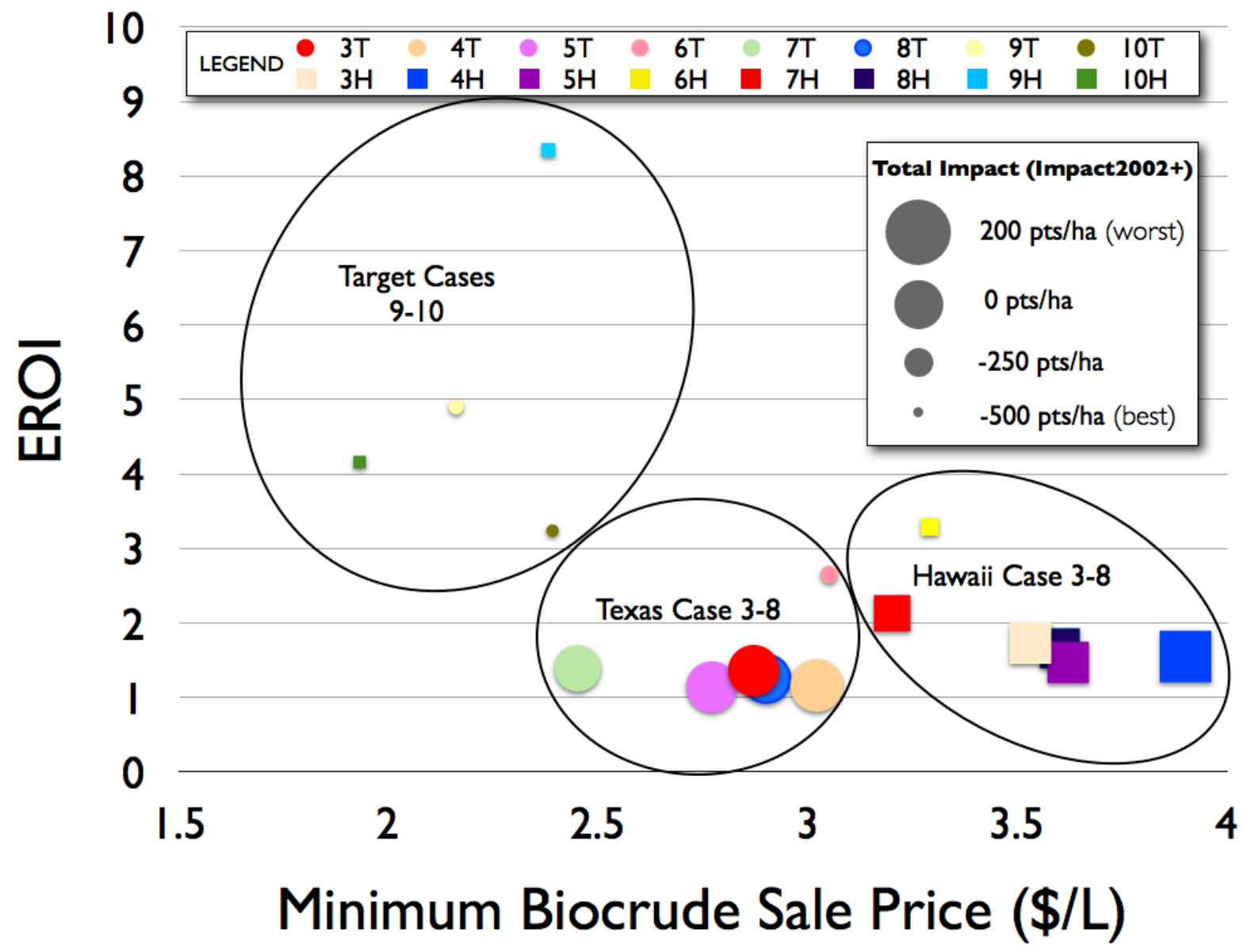

Figure 7. EROI versus minimum biocrude sale price. The size of each marker indicates the overall LCA impact in pts/ha. The target cases are the most favorable, yielding high EROI and low biocrude prices. The cases in Texas generally yield lower biocrude sale prices than those in Hawaii. 


\section{$\underline{3.2 \text { Sensitivity Analysis }}$}

Before discussing the sensitivity analysis, it is useful to identify the most impactful financial contributions in this model. These parameters also serve as targets for future research aimed at lowering the cost of algal biofuel and feed production. The parameters listed in Table 2 are critical for cost and energy balances and are incorporated into the sensitivity analysis below along with factors that have strong impacts on the LCA results.

Table 2. Ten most-impactful contributions to Cases 4-8T. Values given in millions of dollars of cost or revenue over a 30 -year period. Negative values indicate revenue.

\begin{tabular}{|r|l|l|l|l|l|}
\hline & Case 4T & Case 5T & Case 6T & Case 7T & Case 8T \\
\hline 1 & Animal Feed (-63.5) & Animal Feed (-63.5) & Animal Feed (-63.5) & Biocrude (-70.4) & Animal Feed (-91.3) \\
\hline 2 & Biocrude (-46.7) & Biocrude (-46.7) & Biocrude (-46.7) & Labor (41.1) & Biocrude (-39.0) \\
\hline 3 & Labor (41.1) & Labor (41.1) & Labor (41.1) & Interest (18.8) & Labor (41.1) \\
\hline 4 & Insurance (19.5) & Insurance (16.8) & Interest (17.5) & Insurance (16.3) & Interest (16.3) \\
\hline 5 & Maintenance (19.5) & Maintenance (16.8) & Insurance (17.4) & Maintenance (16.3) & Piping (16.1) \\
\hline 6 & Interest (17.5) & Interest (16.4) & Maintenance (17.4) & Piping (16.1) & Insurance (15.1) \\
\hline 7 & Piping (16.1) & Piping (16.1) & Piping (16.1) & Pond Liner (12.8) & Maintenance (15.1) \\
\hline 8 & Pond Liner (12.8) & Pond Liner (12.8) & Pond Liner (12.8) & Water Supply (9.3) & Pond Liner (12.8) \\
\hline 9 & Nitrogen (11.4) & Nitrogen (12.6) & Nitrogen (11.4) & Pond Circulation (6.8) & Nitrogen (12.6) \\
\hline 10 & Water Supply (9.4) & Water Supply (9.4) & Water Supply (10.4) & CHG Equipment (4.1) & Water Supply (9.4) \\
\hline
\end{tabular}

As described by Sills et al., the most effective way to evaluate uncertainty in the TEA/LCA results is to incorporate specific uncertainty ranges for every single parameter in the study.[22] However, that approach was unmanageable for this study because there are more than 80 independent variables, 20 end-to-end cases, and three assessment efforts (energetic, economic, and environmental), all of which would need unique uncertainty functions for each variable. Furthermore, many of the parameters do not have a well-known uncertainty range. Thus, in lieu of a complete Monte Carlo uncertainty analysis, we conducted a sensitivity analysis on Cases 4$8 \mathrm{~T}$ to evaluate the variability in the TEA/LCA results using the less favorable, baseline, and more favorable values shown in Table 3. 
Table 3. Sensitivity analysis parameters: values for less favorable, baseline, and more favorable scenarios. * Using the non-renewable energy impact rather than the total impact has favorable impacts on some cases and unfavorable impacts on others.

\begin{tabular}{|l|c|c|c|}
\hline \multicolumn{1}{|c|}{ Sensitivity Parameters } & Less Favorable & Baseline & More Favorable \\
\hline Biomass Productivity $\left(\mathrm{g} / \mathrm{m}^{2}-\mathrm{d}\right)$ & 18 & 24 & 30 \\
\hline Lipid Content (-) & 0.28 & 0.38 & 0.47 \\
\hline Airlift Efficiency (-) & 0.15 & 0.25 & 0.35 \\
\hline $\begin{array}{l}\text { Biocrude Recovery Efficiency (-) } \\
\text { Valicor:HTL:OpenAlgae }\end{array}$ & $0.7: 0.35: 0.5$ & $0.9: 0.5: 0.75$ & $0.95: 0.65: 0.9$ \\
\hline $\mathrm{CO}_{2}$ Concentration (-) & 0.1 & 0.94 & $\mathrm{NA}$ \\
\hline Cost of $\mathrm{CO}_{2}(\$ / \mathrm{MT})$ & $\$ 40 / \mathrm{MT}$ & 0 & $\mathrm{NA}$ \\
\hline Stoichiometric N:P $(\%$ AFDW) & $8.1: 0.7$ & $6.5: 0.6$ & $4.9: 0.4$ \\
\hline Labor Cost $(\$ \mathrm{M} / \mathrm{yr})$ & 1.7 & 1.4 & 1.0 \\
\hline Non-Renewable vs. Total Energy & Non-Renewable* & Total & Non-Renewable* \\
\hline Discount Rate (\%), Tax Rate (\%) & $15 \%, 35 \%$ & $10 \%, 15 \%$ & $5 \%, 0 \%$ \\
\hline Interest Rate (\%), Loan Term (yr) & $12 \%, 5$ & $8 \%, 10$ & $4 \%, 15$ \\
\hline Animal Feed Price (\$/MT) & 300 & 600 & 1,500 \\
\hline Capital Cost & $125 \%$ of Baseline & Baseline & $75 \%$ of Baseline \\
\hline Operating Days (days/yr) & 329 & 347 & 360 \\
\hline
\end{tabular}

Using the non-renewable energy impact rather than the total energy impact [47] has favorable impacts on the EROI for some cases and unfavorable impacts on other cases. For all inputs and outputs, the non-renewable energy impact is less than the total energy impact (see Table D-3 in the SI). For instance, the non-renewable energy impact for wind power is $0.05 \mathrm{MJ} / \mathrm{MJ}$, while the total energy impact is $1.13 \mathrm{MJ} / \mathrm{MJ}$ - accounting for the kinetic wind energy. Similarly, the nonrenewable energy impact for animal feed is $3.58 \mathrm{MJ} / \mathrm{MJ}$, while the total energy impact is 25.08 $\mathrm{MJ} / \mathrm{MJ}$ - accounting for the biomass energy content. Thus, using the non-renewable impact can increase or decrease the EROI depending on whether the numerator or denominator is more strongly affected, as shown in Figure 8. The LCA impacts use the Impact2002+ method, which can only accommodate non-renewable resource impacts (e.g., fossil-fuels, uranium, etc.), and therefore aggregate LCA impacts cannot be determined for total (renewable and non-renewable) resource impacts. 
These five cases (Cases 4-8T) represent base case scenarios for four separate production pathways - they are based on models for the current state of technologies and include pathways for the Valicor, HTL, and OpenAlgae processes. The results are presented in the following three metrics: EROI (unitless), minimum biocrude sale price (\$/L), and aggregate LCA impact (pt/ha), which is the sum of the four LCA impact categories with like units. All of the sensitivity analysis results are presented in Appendix I of the SI.

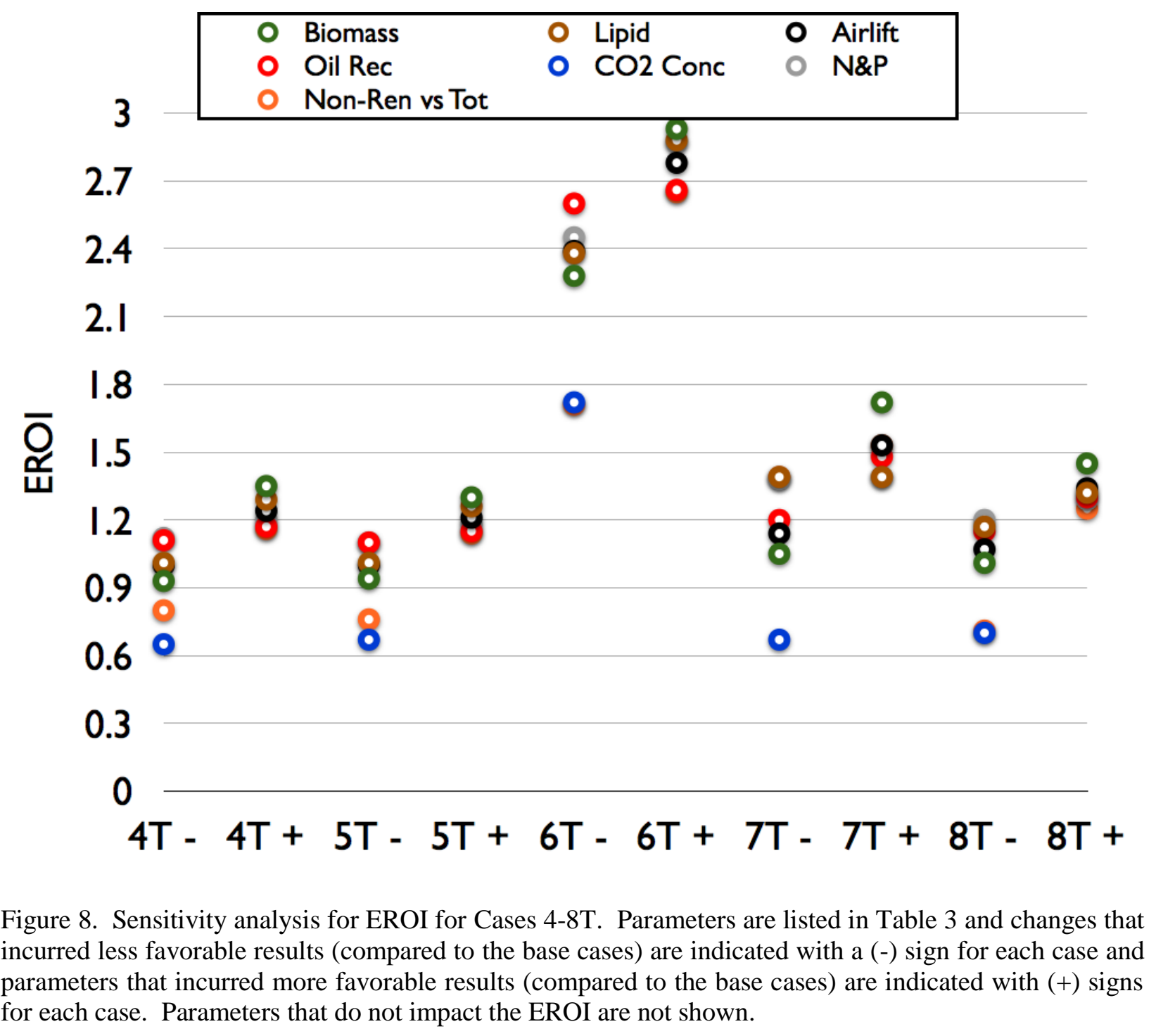




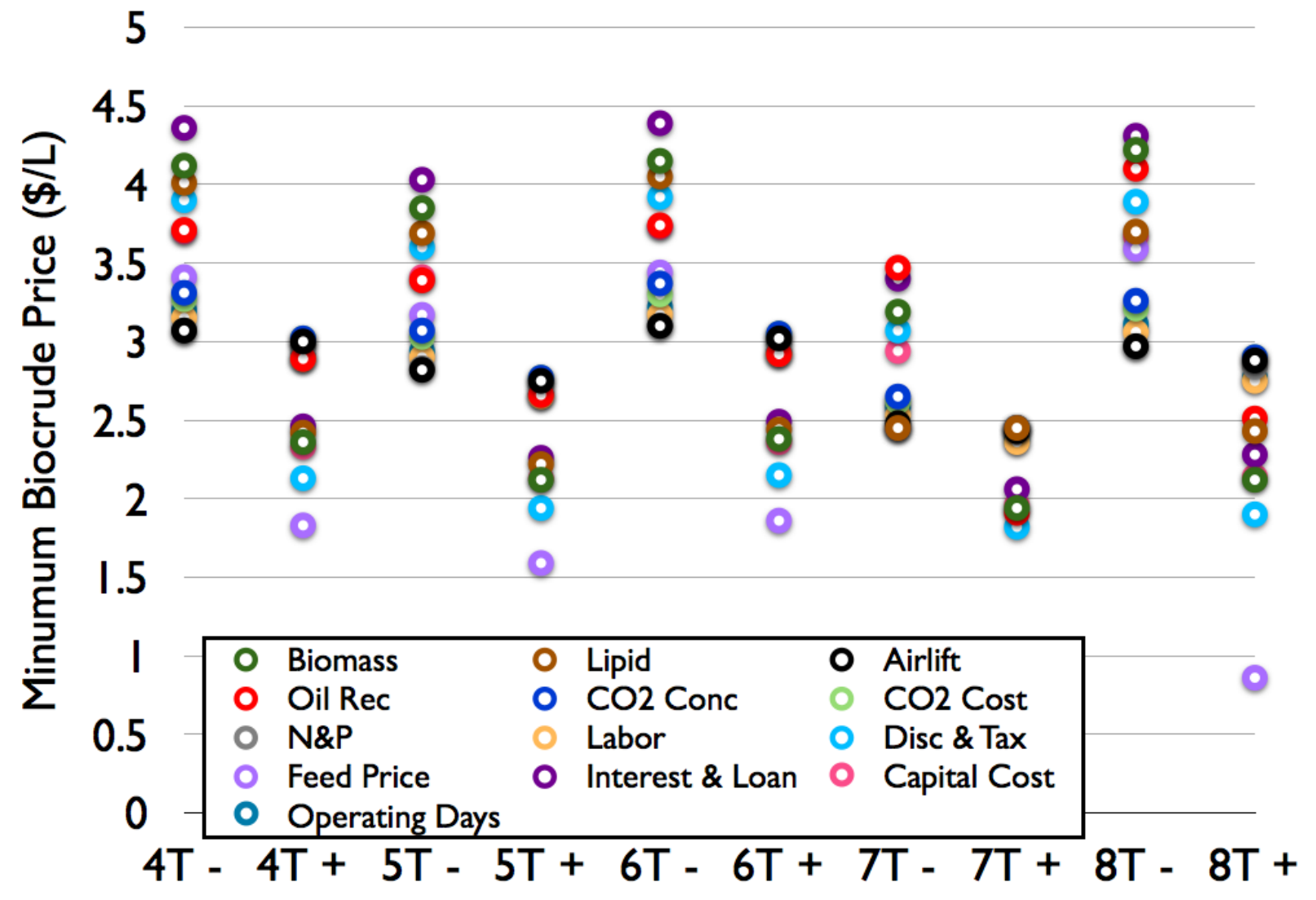

Figure 9. Sensitivity analysis for minimum biocrude sale price for Cases 4-8T. Parameters are listed in Table 3 and changes that incurred less favorable results (compared to the base cases) are indicated with a (-) sign for each case and parameters that incurred more favorable results (compared to the base cases) are indicated with $(+)$ signs for each case. Parameters that do not impact the minimum biocrude sale price are not shown. 


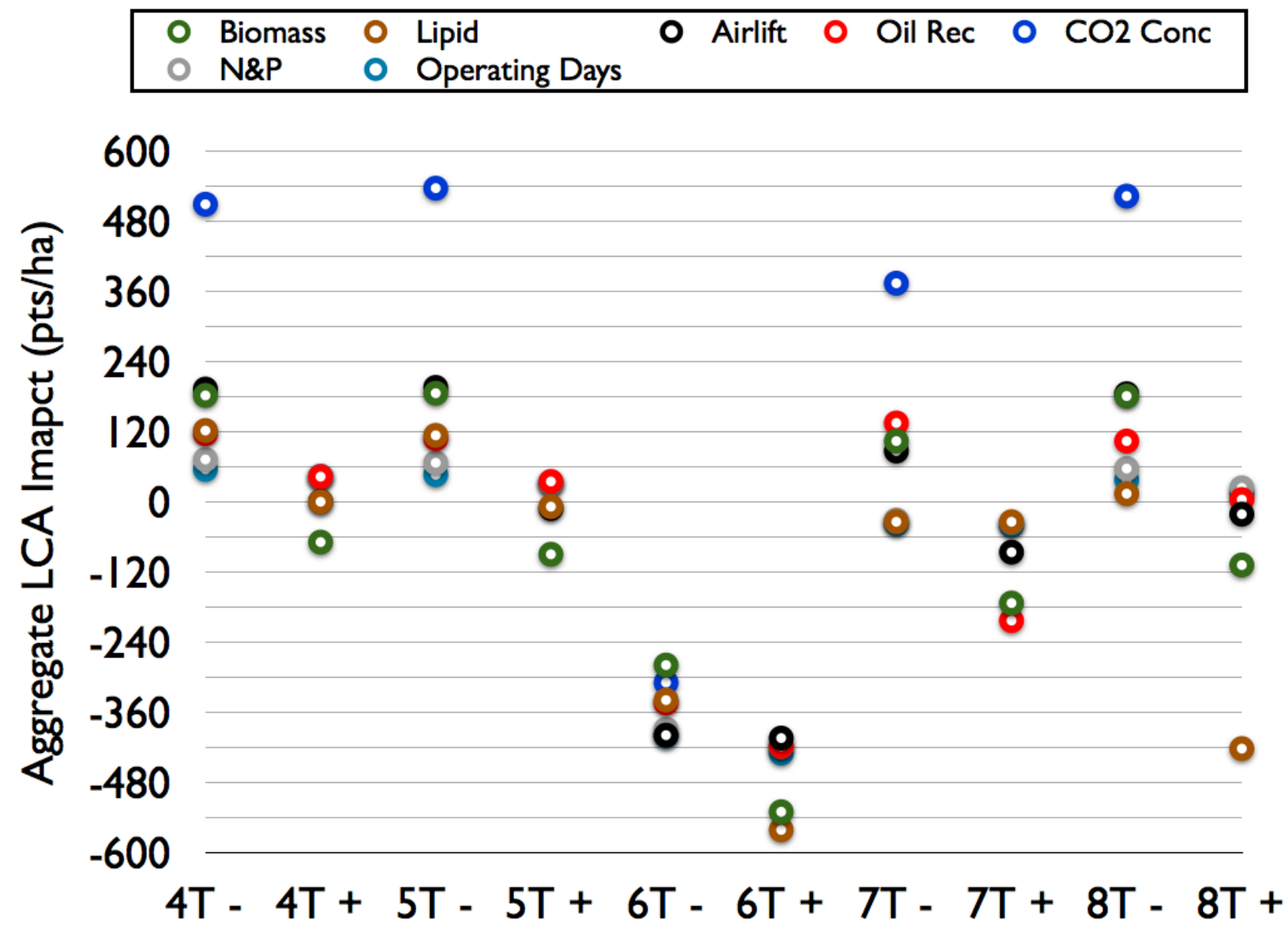

Figure 10. Sensitivity analysis for aggregate LCA impact for Cases 4-8T. Parameters are listed in Table 3 and changes that incurred less favorable results (compared to the base cases) are indicated with a (-) sign for each case and parameters that incurred more favorable results (compared to the base cases) are indicated with (+) signs for each case. Parameters that do not impact the LCA impacts are not shown. The Impact2002+ method only accommodates non-renewable resource impacts, and thus the aggregate LCA impact for total resources cannot be determined.

For EROI and LCA impacts, changing the concentration of $\mathrm{CO}_{2}$ resulted in the largest changes in model results, due to increased volumetric flow rates and the associated electricity consumption. However, the percent change in $\mathrm{CO}_{2}$ concentration ( $90 \%$ change) was bigger than the percent changes in the other parameters studied in the sensitive analysis. We chose to see how changing $\mathrm{CO}_{2}$ concentration from $94 \%$ (typical for hydrogen or cement plants) to $10 \%$ (more typical for a coal- or gas-fired power plant), since the lower-concentration $\mathrm{CO}_{2}$ source is more available. The 
energetics, economics, and environmental impacts were all sensitive to changes in biomass productivity. For EROI, the type of energy analysis (Non-Renewable vs. Total, see Equation 1) was also a sensitive parameter, demonstrating the importance of specifying which analysis is being conducted when comparing EROI values across studies. For the minimum biocrude sale price, changes in the interest rate and loan term, discount and tax rates, biomass and lipid productivities, and the price of animal feed impacted model results the most. Some of the most important parameters in this model could not be evaluated in a sensitivity analysis because changes in those parameters would require an entire system re-design. These include: slope of the land, supernatant and sludge pumping rather than gravity flow, algal species, pond and PBR dimensions (length, depth, etc.), settling characteristics, and variations in the ratio of PBRs:1-day ponds:2-day ponds. Changes to these parameters can have significant impacts on the productivity, costs, and energy balance.

\section{$\underline{3.3 \text { Discussion }}$}

\subsubsection{Overview}

This study yields several encouraging results. There are six cases with an EROI $>1.5$, a minimum biocrude sale price $<\$ 3.50 / \mathrm{L}$, and a beneficial aggregate environmental LCA impact $(6 \mathrm{~T}, 9 \mathrm{~T}, 10 \mathrm{~T}, 6 \mathrm{H}, 7 \mathrm{H}, 9 \mathrm{H}$, and $10 \mathrm{H})$. Although these cases rely on renewable electricity sources, even the cases with grid electricity show promise, such as Cases 7 and 8 in Texas and Hawaii, which yield EROI values between 1.25 and 2.13 and minimum biocrude sale prices between $\$ 2.45 / \mathrm{L}$ and $\$ 3.60 / \mathrm{L}$. The environmental impacts of these cases are roughly neutral. Although the baseline cases in this study yield minimum biocrude sale prices around $\$ 2.64 / \mathrm{L}$ ( $\$ 10 /$ gallon), 
if the co-product revenue is increased (as shown in the sensitivity analysis), the minimum sale prices can be as low as $\$ 0.86 / \mathrm{L}$ ( $\$ 3.26 /$ gallon, Case $8 \mathrm{~T}+$ in Figure 9$)$, which is economically competitive in current markets. There are several potential co-products that could yield \$1500/MT, such as omega-3 fatty acid human nutrition supplements [59-61] and aquafeeds [62, 63]. Results from this study for minimum biocrude sale price are compared with others from the literature in Figure 11.

\section{Comparison of biocrude and biofuel production costs with previous studies}

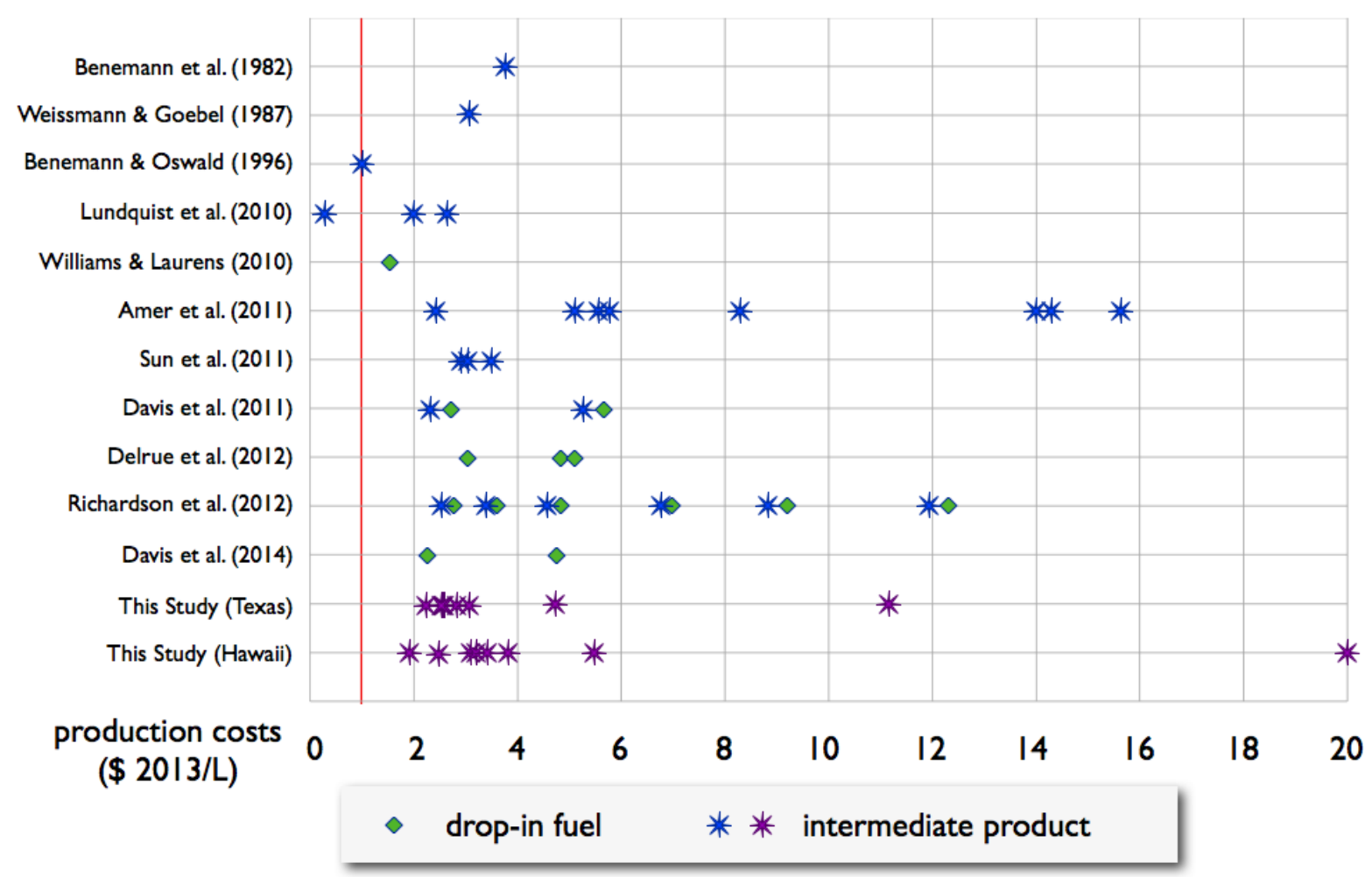

Figure 11. Minimum biocrude sale price: comparison of results from this study (in purple) and those in the literature (in blue). The red line shows the average price of diesel for comparison.[7, 18, 23, 28, 6470] 


\subsubsection{Resource Constraints}

While this study provides many promising and progressive results for algal biofuel production, it also reveals significant limitations. Algal biofuel and animal feed production are limited by the accessibility of waste carbon as well as nitrogen and phosphorus fertilizer. The proximity and quality of the carbon source is one of the most important parameters for algal biofuel production and there have been numerous studies devoted to evaluating carbon availability and the feasibility of different sources.[71-75] This model assumes that a waste source of nearly pure $\mathrm{CO}_{2}(94 \%)$ is available at no cost. While such concentrated $\mathrm{CO}_{2}$ sources exist (e.g., hydrogen plants, cement plants, etc.), they are comparatively rare. Widespread algae production would require additional sources - such as flue gas - and the collection, purification, and distribution of that carbon would incur additional energetic and financial costs, as shown in the sensitivity analysis. The silicon requirement for diatom production creates several disadvantages: additional energetic and financial costs, difficult nutrient preparation methods, and high ash content in the residual animal feed. As shown in Table 4, in order to satisfy the Renewable Fuel Standards mandate with 18.9 billion liters of annual biocrude production from algae (roughly $3 \%$ of the U.S. petroleum demand), the U.S. would require from as little as a $1 \%$ increase in both national nitrogen and phosphorus consumption, to as much as a $33 \%$ and $21 \%$ increase in national nitrogen and phosphorus consumption, respectively. These results demonstrate the importance of nutrient recycling, which is greatly facilitated using HTL (Cases 7 and 9, achieving roughly $92 \%$ nutrient recycling) and to a much lesser degree by using $\mathrm{CHG} / \mathrm{CHP}$ with the aqueous phase remaining after the Valicor process (Cases $2-6$, achieving 9\% nutrient recycling). It is important to note that although there are large nutrient requirements for the Valicor and OpenAlgae cases, both routes produce significant amounts of animal feed (in contrast to HTL), thereby eliminating large flows of nutrient requirements for conventional feed 
production, which on a global scale is less than $50 \%$ efficient in the use of nitrogen fertilizer [76], causing widespread eutrophication [77].

Table 4. Carbon, silicon, nitrogen, and phosphorus requirements for 18.9 billion liters of annual biocrude production ( 5 billion gallons) for the 10 cases. The data in parentheses indicate the percentage of the total U.S. nitrogen and phosphorus consumption (2011) required for these nutrient demands [78] or the percentage of the U.S. soybean meal animal feed market (roughly 27 million MT per year $[76,79]$ ) that would be displaced. Unless noted, data are in thousand MT per year.

\begin{tabular}{|c|c|c|c|c|c|c|c|c|c|c|}
\hline Case & 1 & 2 & 3 & 4 & 5 & 6 & 7 & 8 & 9 & 10 \\
\hline Carbon Demand & 55,403 & 31,093 & 39,102 & 33,090 & 33,090 & 33,090 & 21,964 & 39,708 & 21,964 & 39,708 \\
\hline Silicon Demand & 1,028 & 577 & 977 & 0 & 0 & 0 & 0 & 0 & 0 & 0 \\
\hline Nitrogen Demand & 3,800 & 1,778 & 3,021 & 2,825 & 3,109 & 2,825 & 162 & 3,730 & 162 & 3,730 \\
$(33 \%)$ & $(15 \%)$ & $(26 \%)$ & $(24 \%)$ & $(27 \%)$ & $(24 \%)$ & $(1 \%)$ & $(32 \%)$ & $(1 \%)$ & $(32 \%)$ \\
\hline Phosphorus Demand & $\begin{array}{c}346 \\
(20 \%)\end{array}$ & $\begin{array}{c}176 \\
(10 \%)\end{array}$ & $\begin{array}{c}300 \\
(17 \%)\end{array}$ & $\begin{array}{c}280 \\
(16 \%)\end{array}$ & $\begin{array}{c}309 \\
(18 \%)\end{array}$ & $\begin{array}{c}280 \\
(16 \%)\end{array}$ & $\begin{array}{c}16 \\
(1 \%)\end{array}$ & $\begin{array}{c}371 \\
(21 \%)\end{array}$ & $\begin{array}{c}16 \\
(1 \%)\end{array}$ & $\begin{array}{c}371 \\
(21 \%)\end{array}$ \\
\hline $\begin{array}{c}\text { Animal Feed Yield } \\
(39,244\end{array}$ & $\begin{array}{c}35,536 \\
(131 \%)\end{array}$ & $\begin{array}{c}48,892 \\
(180 \%)\end{array}$ & $\begin{array}{c}24,980 \\
(92 \%)\end{array}$ & $\begin{array}{c}24,980 \\
(92 \%)\end{array}$ & $\begin{array}{c}24,980 \\
(92 \%)\end{array}$ & $\begin{array}{c}0 \\
(0 \%)\end{array}$ & $\begin{array}{c}43,069 \\
(158 \%)\end{array}$ & $\begin{array}{c}0 \\
(0 \%)\end{array}$ & $\begin{array}{c}43,069 \\
(158 \%)\end{array}$ \\
\hline $\begin{array}{c}\text { Land Required } \\
\text { (thousand ha) }\end{array}$ & 2,063 & 1,158 & 844 & 789 & 789 & 789 & 523 & 946 & 523 & 946 \\
\hline $\begin{array}{c}\text { Fresh Water Savings } \\
\left.\text { (billion } \mathrm{m}^{3} / \mathrm{yr}\right)\end{array}$ & 7.5 & 3.2 & 4.5 & 2.2 & 3.7 & 2.3 & $\sim 0.0$ & 3.9 & $\sim 0.0$ & 4.0 \\
\hline
\end{tabular}

\subsubsection{Large-scale Impacts}

Case 4 was designed to represent a facility and operations as if it were to be "built today." It represents the Base Case in [10] and lies between the more-proven, but inefficient Cases 1-3 and the optimistic, but less-proven Cases 5-10. Large-scale production is more likely to occur in the southern continental U.S. [75], thus we can use Case 4T to evaluate the large-scale impacts of these results. We recognize that resource consumption, including land and water use, can vary substantially on a site-specific basis, which leads to inherent constraints on the coverage of this analysis, but these values are provided to give readers a sense of scale for algal fuel and feed production from this integrated system.

The EROI for Case $4 \mathrm{~T}$ is 1.16 , which indicates a positive energy balance and a return on investment similar to U.S. oil shale deposits [80] and corn ethanol produced in the U.S. [81]. 
However, low EROI values - particularly an EROI $<3$ - have been linked to economic recession [82]. There are similar financial challenges. Although Case 4T would achieve a break-even point after 30 years with minimum biocrude or animal feed sale prices of $\$ 3.02 / \mathrm{L}$ and $\$ 2,444 /$ MT (Figure 4), if these products can only fetch market prices for less valuable products, the venture does not reach a break-even cumulative discounted cash flow within 40 years of operation, thereby preventing actual investment. Clearly, a break-even cumulative discounted cash flow that exceeds the expected facility lifetime (30 years) would prevent actual investment. For a viable algal biofuels industry, high-value products are required, fetching the minimum sale prices shown in Figure 4. The ability to achieve the high values listed in Figure 4 for algal biocrude and algae meal for animal feed is therefore a critical area for future study. Due to the water intensive nature of corn and soybean production $\left(246 \mathrm{~m}^{3}\right.$ and $42 \mathrm{~m}^{3}$ depletion per MT of U.S. corn and soybean meal produced, respectively [47]), replacing corn and soybean meal with algae meal (assuming $25 \%$ of the algae meal replaces corn and $75 \%$ of the algae meal replaces soybean meal - representative of typical poultry and swine diets) for animal feed would provide huge fresh water savings. For instance, producing 18.9 billion liters of biocrude would require 789,000 hectares of land (non-arable, but located near $\mathrm{CO}_{2}$ and seawater, notably less than the estimate by Pate et al. [75]) and 2.2 billion $\mathrm{m}^{3}$ of fresh water would be saved each year (by avoiding the fresh water consumed for conventional animal feed production) - enough to fulfill the water demands of roughly 7.9 million Californians (assuming $757 \mathrm{~L} /$ Californian-day [83]). In addition to the water savings, this production would displace $92 \%$ of the soybean meal animal feed market, thereby freeing current soybean fields for alternative use or preventing further deforestation for global protein production. Of the five environmental impacts evaluated in the LCA, the human health and resource indicators show slight harmful balances, largely as a 
result of the electricity consumption. However, the remaining indicators demonstrate major environmental benefits for large-scale deployment of Case 4T.

\subsubsection{Conclusions}

While this study demonstrates that progress is being made in the field of algal biofuels and bioproducts (as new technologies continue to improve the economic and environmental potential of algae products), it also illustrates that widespread near-term investment is not feasible. Even the most promising cases yield minimum sale prices that exceed expected near-term market commodity prices for petroleum and/or animal feeds. Although the EROI for many cases in this study are greater than unity, which represents energy-positive operation, most cases yield an EROI that is too low to be economically viable (it is estimated that an EROI $>3$ is needed [82]). In addition, the requirements for high purity $\mathrm{CO}_{2}$ and large amounts of fertilizer are barriers to large-scale commercial deployment. Finally, the large capital cost (tens-of-millions of dollars with associated financing) and high risk associated with a large-scale algae production facility also deter realized algae production at commodity scale. Based on the results of this study, potential means of improvement include:

1) Producing additional high-value co-products, such as omega-3 supplements, pharmaceuticals, or cosmetics

2) Improve biomass productivity over $25 \mathrm{~g} / \mathrm{m}^{2}-\mathrm{d}$

3) Developing automated technologies to reduce labor costs

4) Creating advanced pond liner materials and pond designs to reduce capital costs below $\$ 2 / \mathrm{m}^{2}$

5) Integrating algae production with low-cost renewable electricity

6) Using atmospheric carbon and/or waste forms of carbon, nitrogen, and phosphorus 
7) Reducing pipe costs using canals or low-cost materials

With these limitations in mind, it is important to recognize that global fuel and protein demand is projected to rise sharply along with the growing global population. Marine algae represent a potential candidate for large-scale production of both fuel and protein, with the possibility of yielding several other global benefits such as reducing fresh water consumed for agriculture, reducing the amount of arable land required to produce the world's protein (thereby preventing further deforestation, reducing greenhouse gas emissions and other environmental damage), yielding omega-3-fatty-acid rich animal feeds that improve herd health, and providing locallyproduced high-quality petroleum fuel substitutes for applications requiring high energy density transportation fuels (e.g., semi-trucks and airplanes) that other biofuels cannot supply. Thus, despite many remaining barriers (including carbon and nutrient acquisition, high capital costs, and geographic sensitivity), the novel facility design and integrated processing pathways presented in this study represent several options to produce feed and fuel from algae to meet the demands of a rapidly growing world population.

\section{ACKNOWLEDGEMENTS}

Funding for the techno-economic and life cycle assessment was provided by awards from US Department of Energy (DE-EE0003371) and US Department of Agriculture (2011-10006-30361) to the Cornell Marine Algae Biofuels Consortium, and is based on the results of large scale production trials funded by Royal Dutch Shell at Cellana's Kona Demonstration Facility (KDF) for the period from 2007 to 2011. Michael Walsh was supported by the National Biomedical Research Foundation. We thank all members of the Cornell Marine Algae Biofuels Consortium.

\section{CONFLICT OF INTEREST}

Co-author, M. Huntley, has a financial interest in Cellana LLC. 


\section{REFERENCES}

1. Congress, U.S., Energy Independence and Security Act of 2007, One Hundred Tenth Congress of the United States of America, H.R.6. 2007(H.R.6).

2. United States DOE., National Algal Biofuels Technology Roadmap. 2010.

3. Howell K., Exxon Sinks \$600M Into Algae-Based Biofuels in Major Strategy Shift, in The New York Times. 2009.

4. Benemann, J., I. Woertz, and T. Lundquist, Life Cycle Assessment for Microalgae Oil Production. Disruptive Science and Technology, 2012. 1(2): p. 68-78.

5. Richardson, J.W., et al., A financial assessment of two alternative cultivation systems and their contributions to algae biofuel economic viability. Algal Research, 2014. 4(0): p. 96104.

6. Beal C.M., et al., Comprehensive Evaluation of Algal Biofuel Production: Experimental and Target Results. Energies, 2012. 5(6): p. 1943-1981.

7. Davis, R.E., et al., Integrated evaluation of cost, emissions, and resource potential for algal biofuels at the national scale. Environ Sci Technol, 2014. 48(10): p. 6035-42.

8. Quinn, J.C., et al., Microalgae to biofuels lifecycle assessment - Multiple pathway evaluation. Algal Research, 2014. 4(0): p. 116-122.

9. Richardson, J.W., et al., Harvesting and extraction technology contributions to algae biofuels economic viability. Algal Research, 2014. 5(0): p. 70-78.

10. Huntley M., et al., Actual large-scale production of marine microalgae for fuels and feed. Algal Research, In Preparation.

11. Austic, R.E., et al., Potential and Limitation of a New Defatted Diatom Microalgal Biomass in Replacing Soybean Meal and Corn in Diets for Broiler Chickens. Journal of Agricultural and Food Chemistry, 2013. 61(30): p. 7341-7348.

12. Kiron, V., et al., Marine microalgae from biorefinery as a potential feed protein source for Atlantic salmon, common carp and whiteleg shrimp. Aquaculture Nutrition, 2012. 18(5): p. 521-531.

13. Batan L., et al., Net Energy and Greenhouse Gas Emission Evaluation of Biodiesel Derived from Microalgae. Environmental Science \& Technology, 2010. 44(20): p. 79757980.

14. Lardon, L., et al., Life-Cycle Assessment of Biodiesel Production from Microalgae. Environmental Science \& Technology, 2009. 43(17): p. 6475-6481.

15. Clarens A.F., et al., Environmental Life Cycle Comparison of Algae to Other Bioenergy Feedstocks. Environmental Science \& Technology, 2010. 44 (5): p. 1813-1819.

16. Collet P., et al., Life-cycle assessment of microalgae culture coupled to biogas production. Bioresource Technology, 2011. 102: p. 207-214.

17. Jorquera O., et al., Comparative energy life-cycle analyses of microalgal biomass production in open ponds and photobioreactors. Bioresource Technology, 2010. 101(4): p. 1406-1413.

18. Sun, A., et al., Comparative cost analysis of algal oil production for biofuels. Energy, 2011. 36(8): p. 5169-5179.

19. Handler, R.M., et al., Evaluation of environmental impacts from microalgae cultivation in open-air raceway ponds: Analysis of the prior literature and investigation of wide variance in predicted impacts. Algal Research, 2012. 1(1): p. 83-92. 
20. Brennan L. and Owende P., Biofuels from microalgae--A review of technologies for production, processing, and extractions of biofuels and co-products. Renewable and Sustainable Energy Reviews, 2010. 14(2): p. 557-577.

21. Slade, R. and A. Bauen, Micro-algae cultivation for biofuels: Cost, energy balance, environmental impacts and future prospects. Biomass and Bioenergy, 2013. 53: p. 29-38.

22. Sills, D.L., et al., Quantitative uncertainty analysis of Life Cycle Assessment for algal biofuel production. Environmental Science \& Technology, 2013. 47(2): p. 687-94.

23. Davis R., Aden A., and Pienkos P.T., Techno-economic analysis of autotrophic microalgae for fuel production. Applied Energy, 2011. 88(10): p. 3524-3531.

24. Clarens, A.F., et al., Environmental Impacts of Algae-Derived Biodiesel and Bioelectricity for Transportation. Environmental Science \& Technology, 2011. 45(17): p. 7554-7560.

25. Grierson, S., V. Strezov, and J. Bengtsson, Life cycle assessment of a microalgae biomass cultivation, bio-oil extraction and pyrolysis processing regime. Algal Research, 2013. 2(3): p. 299-311.

26. Hou, J., et al., Life cycle assessment of biodiesel from soybean, jatropha and microalgae in China conditions. Renewable and Sustainable Energy Reviews, 2011. 15(9): p. 50815091.

27. Finnveden, G., et al., Recent developments in Life Cycle Assessment. Journal of Environmental Management, 2009. 91(1): p. 1-21.

28. Lundquist, T., et al., A realistic technology and engineering assessment of algal biofuel production. 2010, Energy Biosciences Institute, Univerrsity of California: Berkeley, California. p. 178.

29. Beal C.M., et al., Energy Return on Investment for Algal Biofuel Production Coupled with Wastewater Treatment. Water Environment Research, 2012. 84(9): p. 692-710.

30. Westfalia Separator, Instruction Manual and Parts List No. 1354-9015-001, Model MSD 300-96-777.

31. Beal, C.M., et al., The Energy Return on Investment for Algal Biocrude: Results for a Research Production Facility. BioEnergy Research, 2011. 5(2): p. 341-362.

32. Wiley P.E., Campbell J.E., and McKuin B., Production of Biodiesel and Biogas from Algae: A Review of Process Train Options. Water Environment Research, 2011. 83(4): p. 326-338.

33. Mason P., Dedert Corporation Algae Ring Dryer, Beal C.M., Editor. 2014.

34. KM-TEC, K1 Filter Press, Shell Oil Company, Editor. 2010.

35. Sander, K. and G. Murthy, Life cycle analysis of algae biodiesel. The International Journal of Life Cycle Assessment, 2010. 15(7): p. 704-714.

36. POS Biosciences, Hexane Solvent Extraction, Beal C.M., Editor. 2010: http://www.pos.ca/.

37. Goodall B. and Kadam K., Valicor Conversion Processes, Beal C.M., Editor. 2014, http://www.valicor.com/renewables.aspx.

38. Zhu Y., et al., Development of hydrothermal liquefaction and upgrading technologies for lipid-extracted algae conversion to liquid fuels. Algal Research, 2013. 2: p. 455-464.

39. Thomas H., OpenAlgae Wet Extraction, Beal C.M., Editor. 2014, www.openalgae.com.

40. Turton R., et al., Analysis Synthesis and Design of Chemical Processes. 1998.

41. Wigmosta, M.S., et al., National microalgae biofuel production potential and resource demand. Water Resources Research, 2011. 47(3): p. W00H04. 
42. Johnson, Z.I., Pond evaporation. 2010, Marine Algae Consortium Technical Report. p. 118.

43. Delucchi M.A. and Jacobson M.Z., Providing all global energy with wind, water, and solar power, Part II: Reliability, system and transmission costs, and policies. Energy Policy, 2011. 39: p. 1170 - 1190.

44. Austin Energy. Austin City Council Approves New Wind Contract to Reach Renewable Energy Goal. 2014; Available from:

http://austinenergy.com/wps/portal/ae/about/news/press-releases/austin-city-councilapproves-new-wind-contract-to-reach-renewable-energy-goal/.

45. US Energy Information Administration. Table ET1. Primary Energy, Electricity, and Total Energy Price and Expenditure Estimates, 1970-2012, Texas/Hawaii. 2014 2014]; Available from: http://www.eia.gov/state/seds/data.cfm?incfile=/state/seds/.

46. RS Means Heavy Construction Cost Data, BNI News General Construction 2012 Costbook. 2012.

47. Frischknecht R., et al., The ecoinvent database: Overview and Methodological Framework. International Journal of Life Cycle Assessment, 2005. 10: p. 3-9.

48. USDA. Land Rents, Quick Stats. 2014 12-25-14]; Available from: http://quickstats.nass.usda.gov/results/58B27A06-F574-315B-A8549BF568F17652\#7878272B-A9F3-3BC2-960D-5F03B7DF4826.

49. United States Internal Revenue Service., Publication 946 (2013), How to Depreciate Property, http://www.irs.gov/publications/p946/index.html, Editor. 2013.

50. World Bank. Global Economic Monitor (GEM) Commodities. 2014 2014]; Available from: http://databank.worldbank.org/data/databases/commodity-price-data.

51. US Energy Information Administration. Cushing, OK WTI Spot Price FOB, Crude Oil. 2014 2014]; Available from:

http://www.eia.gov/dnav/pet/hist/LeafHandler.ashx?n=PET\&s=RWTC\&f=D.

52. Nebraska Ethanol Board Nebraska Energy Office. Ethanol and Unleaded Gasoline Average Rack Prices. 2014 [cited 2014 2014]; Available from: http://www.neo.ne.gov/statshtml/66.html.

53. ISO, Environmental management, Life Cycle Assessment, Principles and Framework. 2006, International Standard ISO 14040.

54. ISO, Environmental management, Life Cycle Assessment, Requirements and Guidelines. 2006, International Standard ISO 14044.

55. Gerber L., Gassner M., and Marechal F., Systematic integration of LCA in process systems design: Application to combined fuel and electricity production from lignocellulosic biomass. Computers and Chemical Engineering, 2011. 35: p. 1265 - 1280.

56. Jolliet O., et al., IMPACT 2002+: A new life cycle impact assessment methodology. International Journal of Life Cycle Assessment, 2003. 8(6): p. 324-330.

57. Lautier, A., et al., Development of normalization factors for Canada and the United States and comparison with European factors. Science of The Total Environment, 2010. 409(1): p. 33-42.

58. Goedkoop M., et al., ReCiPe 2008, Ruimte en Milieu., Editor. 2013.

59. Qualitas Health. Qualitas Health and Valicor Renewables announce strategic partnership to commercialize algae-based Omega-3 supplements. 2014; Available from:

http://www.qualitas-health.com/qualitas-health-and-valicor-renewables-announcestrategic-partnership-to-commercialize-algae-based-omega-3-supplements/. 
60. Naturals, N. Algae Omega Liquid. 2014; Available from: http://www.nordicnaturals.com/en/Products/Product_Details/514/?ProdID=1649.

61. Algae, A. Make Way for a Better Omega-3 Source. 2014; Available from: http://www.aurorainc.com/solutions/omega-3/.

62. Leschin-Hoar C., Why Farmed Salmon is Losing its Omega-3 Edge, in Time. 2014: http://time.com/3620869/salmon-omega-3/.

63. Welch L., Fish Factor: Salmon feed prices on the rise; strong chum landings on Yukon. Alaska Journal of Commerce, 2013.

64. Williams P.J. and Laurens M.L., Microaglae as biodiesel \& biomass feedstocks: Rview \& analysis of the biochemistry, energetics, \& economics. Energy \& Environmental Science, 2010. 3: p. 554-590.

65. Delrue, F., et al., An economic, sustainability, and energetic model of biodiesel production from microalgae. Bioresource Technology, 2012. 111(0): p. 191-200.

66. Richardson, J.W., M.D. Johnson, and J.L. Outlaw, Economic comparison of open pond raceways to photo bio-reactors for profitable production of algae for transportation fuels in the Southwest. Algal Research, 2012. 1(1): p. 93-100.

67. Amer, L., B. Adhikari, and J. Pellegrino, Technoeconomic analysis of five microalgae-tobiofuels processes of varying complexity. Bioresource Technology, 2011. 102(20): p. 9350-9359.

68. Benemann J. and Oswald W., Systems and Economic Analysis of Microalgae Ponds for Conversion of CO2 to Biomass. 1996, Department of Energy.

69. Weissmann J.C. and Goebel R.P., Design and analysis of microalgal open pond systems for the purpose of producing fuels: A subcontract report. 1987, Solar Energy Research Institute.

70. Benemann J.R., et al., Microalgae as a source of liquid fuels. 1982, Solar Energy Research Institute.

71. Wogan D.M., An integrated resource and biological growth model for estimating algal biomass production with geographic resolution, in Mechanical Engineering. 2010, University of Texas at Austin: Austin, TX.

72. Kadam K. L., Environmental implications of power generation via coal-microalgae cofiring. Energy, 2002. 27(10): p. 905-922.

73. Huntley M. and Redalje D., CO2 Mitigation and Renewable Oil from Photosynthetic Microbes: A New Appraisal. Mitigation and Adaptation Strategies for Global Change, 2007. 12(4): p. 573-608.

74. Packer, M., Algal capture of carbon dioxide; biomass generation as a tool for greenhouse gas mitigation with reference to New Zealand energy strategy and policy. Energy Policy, 2009. 37(9): p. 3428-3437.

75. Pate R., Klise G., and Wu B., Resource demand implications for US algae biofuels production scale-up. Applied Energy, 2011. 88(10): p. 3377-3388.

76. Canfield, D.E., A.N. Glazer, and P.G. Falkowski, The evolution and future of Earth's nitrogen cycle. Science, 2010. 330(6001): p. 192-6.

77. Galloway, J.N., et al., Transformation of the nitrogen cycle: recent trends, questions, and potential solutions. Science, 2008. 320(5878): p. 889-92.

78. Nehring R. Fertilizer Use and Price, USDA. 2013 [cited 2014 2014]; Available from: http://www.ers.usda.gov/data-products/fertilizer-use-and-price.aspx\#.U_t5GvldVWE. 
79. EPA, U.S. Major Crops Grown in the United States. 2013; Available from: http://www.epa.gov/agriculture/ag101/cropmajor.html.

80. Brandt A.R., Converting oil shale to liquid fuels: Energy inputs and greenhouse gas emissions of the Shell in situ conversion process. Environmental Science \& Technology, 2008. 42(19): p. 7489-7495.

81. Farrell A.E., et al., Ethanol Can Contribute to Energy and Environmental Goals. Science, 2006. 311(5760): p. 506-508.

82. King C.W., Energy intensity ratios as net energy measures of United States energy production and expenditures. Environmental Research Letters, 2010. 5(4).

83. Rogers P. and St. Fleur N., California Drought: Database shows big difference between water guzzlers and sippers, in San Jose Mercury News. 2014. 